\title{
Impact of Bay-Breeze Circulations on Surface Air Quality and Boundary Layer Export
}

\author{
Christopher P. Loughner, ${ }^{*},{ }^{+}$Maria Tzortziou,,${ }^{*+}$ Melanie Follette-CoOK, ${ }^{+, \#}$

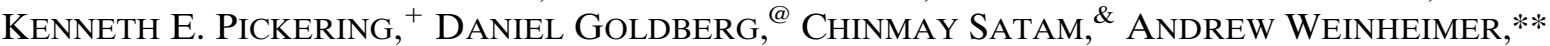 \\ JAMES H. CRAWFORD, ${ }^{\# \#}$ DAVID J. KNAPP, $* *$ DENISE D. MONTZKA, ** GLENN S. DisKIN, ${ }^{\#}$ AND \\ RUSSELL R. DICKERSON ${ }^{\circledR}$ \\ * Earth System Science Interdisciplinary Center, University of Maryland, College Park, College Park, Maryland \\ ${ }^{+}$NASA Goddard Space Flight Center, Greenbelt, Maryland \\ ${ }^{\#}$ Morgan State University, Baltimore, Maryland \\ ${ }^{@}$ Department of Atmospheric and Oceanic Science, University of Maryland, College Park, College Park, Maryland \\ ${ }^{\&}$ Department of Chemical and Biomolecular Engineering, University of Maryland, College Park, College Park, Maryland \\ ** National Center for Atmospheric Research, ${ }^{++}$Boulder, Colorado \\ \#\# NASA Langley Research Center, Hampton, Virginia
}

(Manuscript received 8 October 2013, in final form 6 February 2014)

\begin{abstract}
Meteorological and air-quality model simulations are analyzed alongside observations to investigate the role of the Chesapeake Bay breeze on surface air quality, pollutant transport, and boundary layer venting. A case study was conducted to understand why a particular day was the only one during an 11-day ship-based field campaign on which surface ozone was not elevated in concentration over the Chesapeake Bay relative to the closest upwind site and why high ozone concentrations were observed aloft by in situ aircraft observations. Results show that southerly winds during the overnight and early-morning hours prevented the advection of air pollutants from the Washington, D.C., and Baltimore, Maryland, metropolitan areas over the surface waters of the bay. A strong and prolonged bay breeze developed during the late morning and early afternoon along the western coastline of the bay. The strength and duration of the bay breeze allowed pollutants to converge, resulting in high concentrations locally near the bay-breeze front within the Baltimore metropolitan area, where they were then lofted to the top of the planetary boundary layer (PBL). Near the top of the PBL, these pollutants were horizontally advected to a region with lower PBL heights, resulting in pollution transport out of the boundary layer and into the free troposphere. This elevated layer of air pollution aloft was transported downwind into New England by early the following morning where it likely mixed down to the surface, affecting air quality as the boundary layer grew.
\end{abstract}

\section{Introduction}

Air pollution affects human health (Mudway and Kelly 2000; Dockery et al. 1993; Samet et al. 2000), crop yields (Booker et al. 2009; Fishman et al. 2010; Sanders et al. 1992), aquatic ecosystems (Moffat 1998; Morgan and Owens 2001; Galloway et al. 2003; National Research Council 1995), and climate (Ramanathan and

\footnotetext{
${ }^{++}$The National Center for Atmospheric Research is sponsored by the National Science Foundation.
}

Corresponding author address: Christopher P. Loughner, Earth System Science Interdisciplinary Center, NASA/GSFC Code 614, Greenbelt, MD 20771.

E-mail: christopher.p.loughner@nasa.gov
Feng 2009; Shine 2000; Fishman et al. 1979; Hansen et al. 1997). The buildup of tropospheric trace gases and aerosols is dependent on air-pollution emissions, meteorological conditions, and the chemical processes occurring in the atmosphere. The complex nature of air-pollution formation and buildup can be simulated with a combination of meteorological and air-quality models, and observations are critical in evaluating the models. Meteorological and air-quality model simulations provide a full picture of the conditions (if accurate), whereas observations are more spotty. Therefore, the use of models alongside observations is useful for investigating how pollutants evolve in the atmosphere, forecasting air quality and the climatic impacts of pollutants, and helping to formulate air-pollution and climatic-change mitigation plans.

DOI: 10.1175/JAMC-D-13-0323.1 
Previous studies have shown that sea-, bay-, or lakebreeze circulations can contribute to poor air quality. For example, along the Portuguese west coast surface ozone levels typically become higher when a sea breeze is present (Evtyugina et al. 2006). In Southern California, the peak surface ozone concentrations on high-ozone days have been found to occur at the farthest-inland location of a sea breeze's convergence zone (Boucouvala and Bornstein 2003). In Houston, Texas, high surface ozone episodes typically begin when the synoptic-scale winds transport pollutants from land to sea prior to the onset of a bay breeze (Banta et al. 2005; Darby 2005). As the bay breeze begins to develop, stagnant conditions ensue as the winds over the water begin to reverse direction, allowing ozone and ozone precursors to accumulate before being advected onshore as the bay breeze increases in intensity later in the afternoon. In addition, a Southeast Asian study found that sea-breeze circulations affect the distribution of smoke (Wang et al. 2013). A study during July of 2011 showed that surface ozone concentrations are usually higher over the Chesapeake Bay than over upwind areas as a result of lower deposition rates, ship emissions trapped in a shallow planetary boundary layer, higher photolysis rates, and decreased boundary layer venting due to fewer clouds being present in comparison with the adjacent land (Goldberg et al. 2014). In the Washington, D.C., and Baltimore, Maryland, metropolitan areas, a bay-breeze case study (Loughner et al. 2011) was analyzed in which synoptic-scale winds were westerly, and it was found that 1) prior to the development of the bay breeze, westerly winds transport pollutants from urban areas out over the surface waters of the Chesapeake Bay; 2) as the bay breeze begins to form, stagnation develops over the bay, allowing pollutants to accumulate as the winds begin to change to a southerly direction; and 3) once the bay breeze forms, southerly winds over the bay transport the high concentrations of surface pollutants that accumulated over the bay northward across the coastline. The bay breeze typically enhances air-pollution events at Edgewood, Maryland, which is on the northern coastline of the Chesapeake Bay, making it the most polluted site in Maryland for ozone. In addition, it was found that, once the Chesapeake Bay breeze forms, surface pollutants over land cannot be transported near the surface across the coastline but instead are transported to the bay-breeze convergence zone where they are lofted and then transported downwind (Loughner et al. 2011).

Combining model simulations with detailed observations at the land-ocean interface is essential for testing the theoretical understanding of the atmosphere as expressed in state-of-the-art photochemical models and for improving knowledge of the impacts of coastal processes on local pollution episodes. Here, we examine the role of the Chesapeake Bay breeze on air quality and pollutant transport from the planetary boundary layer (PBL) to the free troposphere on 11 July 2011, which was an observation day during two simultaneous field campaigns in the region: the Deriving Information on Surface Conditions from Column and Vertically Resolved Observations Relevant to Air Quality project (DISCOVER-AQ; http://discover-aq. larc.nasa.gov) and the Geostationary Coastal and Air Pollution Events-Chesapeake Bay Oceanographic Campaign with DISCOVER-AQ (GeoCAPE-CBODAQ; Tzortziou et al. 2014; http://neptune.gsfc.nasa.gov/osb/ index.php?section $=250$ ).

The DISCOVER-AQ project is a National Aeronautics and Space Administration (NASA) Earth Venture mission comprising four deployments of aircraft- and ground-based measurement networks. These measurement campaigns are designed to improve the interpretation of satellite observations to diagnose near-surface conditions relating to air quality. The first of four deployments took place over the Washington and Baltimore metropolitan area and the Chesapeake Bay throughout July of 2011. Two aircraft were used, the NASA P-3B for in situ sampling in the lowest $3 \mathrm{~km}$ of the atmosphere and the NASA UC-12 flying at approximately $9 \mathrm{~km}$ with remote sensing instruments for trace gases and aerosols. In addition, extensive ground observations were used to measure air pollution at the surface using in situ observations and aloft using balloons and remote sensing instruments. Field observations at Edgewood during the DISCOVER-AQ field campaign revealed that the bay-breeze circulation was evident on nine days at this location during July 2011 (Stauffer et al. 2014). The GeoCAPE-CBODAQ field campaign complemented the DISCOVER-AQ by making ship-based measurements of air and water quality from 11 to 20 July 2011.

In this study, we use results from meteorological and air-quality model simulations, airborne and shipborne in situ air-quality observations, and routine air-quality and meteorological observations from ground-based monitoring stations to investigate how the Chesapeake Bay breeze affects air quality. We focus on the transport processes that took place on 11 July for two reasons: 1) this was the only day on which ozone concentrations were not increased above baseline over the bay relative to the closest upwind ground-based monitoring stations (Goldberg et al. 2014), contributing to lower observed ozone concentrations at Edgewood than at nearby monitoring sites to the west, and 2) increased levels of air pollution were observed aloft by in situ observations 
on board the NASA P-3B aircraft relative to surface concentrations (to be shown and discussed further below). Past research on the relationship of the Chesapeake Bay breeze and air quality showed increased pollution levels over the bay waters that were due to stagnation that develops over the water as the winds begin to change direction as a result of bay-breeze development (Loughner et al. 2011). In addition, lower deposition rates and PBL heights over the water contribute to high air-pollution concentrations over coastal urban waters (Angevine et al. 2004; Martins et al. 2012). We focus on this event to gain an understanding of why air-pollution levels over the surface waters of the bay were not higher than over nearby land and why high concentrations were observed aloft. We also investigate how the Chesapeake Bay breeze affected surface air quality and pollutant transport and whether the high concentrations of pollutants aloft reached the free troposphere, as this would have important implications on air quality far downwind.

\section{Model description}

In this study, we used the U.S. Environmental Protection Agency (EPA) Community Multiscale Air Quality (CMAQ; Byun and Schere 2006) model, version 5.0 , which is driven offline by output from the Weather Research and Forecasting (WRF; Skamarock et al. 2008) model, version 3.3, to simulate the state of the atmosphere covering the entire months of June and July of 2011. The WRF model simulations were performed at high resolution (horizontal resolution up to $1.3 \mathrm{~km}$ ) to capture local-scale bay-breeze circulations. The simulations begin on 24 May 2011 to account for model spinup time.

Meteorological fields are passed to CMAQ at 1-h time intervals. Passing the meteorological conditions into an air-quality model at a higher temporal resolution or running the chemistry online within a meteorological model is preferable but requires significantly more computational resources (Grell et al. 2004). In our case, the demand for computer disk space for passing the meteorological fields into the air-quality model at higher resolutions or the computational power that would be required for running an online meteorological and airquality model was too high to run the models up to 1.3-km horizontal resolution. Even though performing offline high-spatial-resolution air-quality model simulations with coarse temporal meteorological inputs adds some uncertainty to the results by underestimating the variability of vertical transport (Grell et al. 2004), this approach has been used in a number of previous studies to allow for key insights to be gained on how complex environments (i.e., topography, coastlines, urban centers, and industrial complexes) and/or small-scale processes (i.e., sulfate formation and boundary layer venting through fair-weather cumulus clouds and localscale circulations, such as sea breezes) affect air quality (Gonçalves et al. 2009; Im et al. 2010; Jimenez et al. 2005, 2006, 2007; Lee et al. 2008; Loughner et al. 2011; Ortega et al. 2009; Parra et al. 2006; Perez et al. 2006; San Jose et al. 2007; Stein et al. 2007; Yu et al. 2008). In this paper, we use these high-resolution simulations to capture the complex geometry of the Chesapeake Bay and accurately simulate the bay breeze. Previous research has shown that coarse-resolution $(>5 \mathrm{~km})$ model simulations may not be able to capture this local-scale circulation (Loughner et al. 2011).

In addition, recent work has shown that highresolution CMAQ simulations improve the representation of vertical transport and boundary layer venting in the model (Loughner et al. 2011). It has been suggested that CMAQ simulations with resolutions of $12 \mathrm{~km}$ underestimate boundary layer venting on the basis of a positive model bias in sulfur concentrations throughout the eastern United States (Mueller et al. 2006). Increasing convective venting causes pollutants to have longer lifetimes and to be transported greater distances, exacerbating air pollution downwind (Cooper et al. 2010). Previous studies showed that CMAQ run with a horizontal resolution of $12 \mathrm{~km}$ underestimates interstate transport of pollutants (Gilliland et al. 2008; Godowitch et al. 2010). Improved meteorological data assimilation in WRF has been used to improve horizontal transport (Gilliam et al. 2012). A more recent study has shown that, as the resolution increases, vertical mixing increases within the boundary layer and between the PBL and the free troposphere (Loughner et al. 2011). In addition, uncertainties and errors in the chemistry and chemical lifetime within CMAQ may result in errors in regional transport (Gilliland et al. 2008). This study was done by comparing CMAQ simulations run with horizontal resolutions of 13.5, 4.5, 1.5, and $0.5 \mathrm{~km}$ (Loughner et al. 2011). Results discussed in section 4 below show that the highresolution model simulations are able to capture the vertical transport related to the local-scale bay-breeze circulation.

\section{a. Meteorological model}

The WRF model, used to simulate the meteorological conditions, is run with one-way nested domains at 36-, $12-, 4-$, and $1.33-\mathrm{km}$ horizontal resolution with dimensions of $149 \times 129,175 \times 175,172 \times 220$, and $274 \times$ 307 grid cells, respectively (see Fig. 1 for the model domains). All domains have 34 vertical levels from the surface to $100 \mathrm{hPa}$, with 16 levels within the lowest $2 \mathrm{~km}$ 

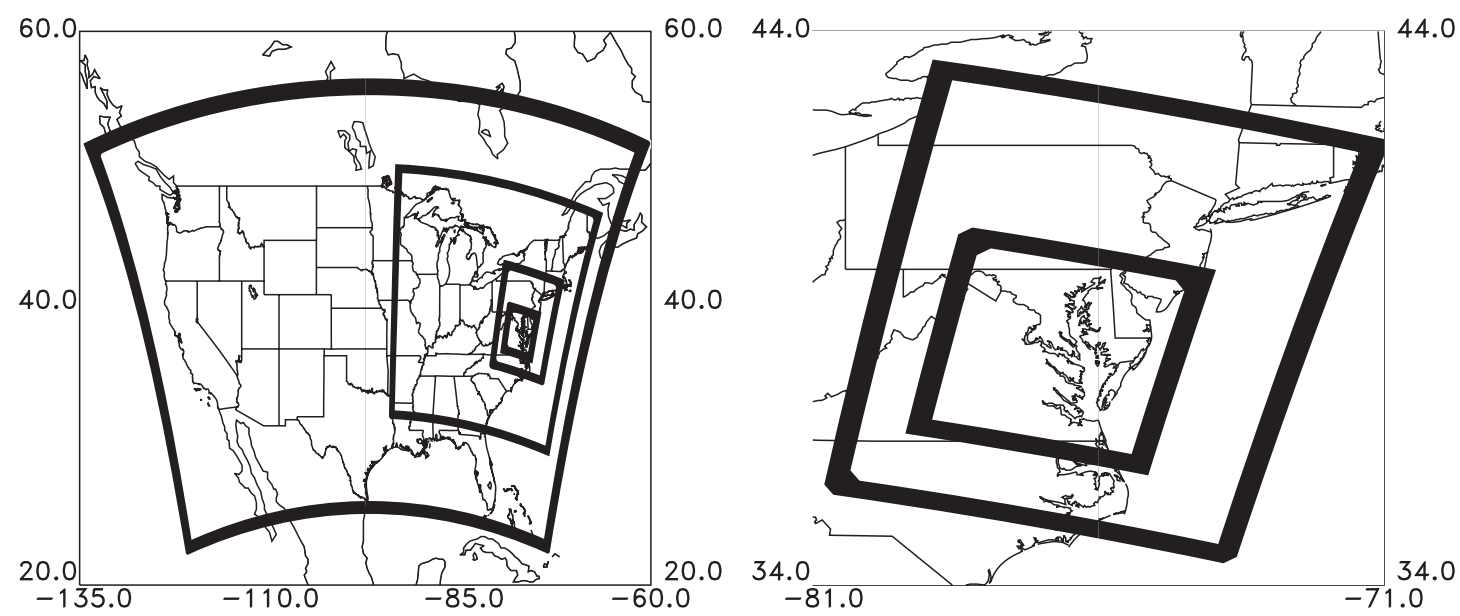

FIG. 1. Diagram showing (left) the four modeling domains and (right) the two innermost domains. The four domains have horizontal resolutions of $36,12,4$, and $1.33 \mathrm{~km}$.

so as to simulate boundary layer processes accurately. The domain with 1.33-km horizontal resolution covers Washington, Baltimore, and the Chesapeake Bay and is at a high enough resolution to simulate local-scale baybreeze events. Model-simulated fields were output hourly. The North American Regional Reanalysis is used for the model initial and outermost lateral boundary conditions. The water surface temperature in the model is from the Multiscale Ultrahigh Resolution sea surface temperature analysis, which has a resolution of $0.01^{\circ}$, or $\sim 1 \mathrm{~km}$. The model is run with the Pleim-Xiu surface layer scheme (Pleim 2006) and the Pleim-Xiu land surface model (Xiu and Pleim 2001) to calculate surface fluxes of heat, moisture, and momentum; the Asymmetric Convective Model 2 (ACM2; Pleim 2007) to compute mixing in the PBL; the WRF single-moment six-class microphysics scheme (WSM-6) to calculate water vapor, cloud water, rain, cloud ice, snow, and graupel (Hong and Lim 2006); and the Kain-Fritsch convective parameterization to simulate subgrid clouds and vertical transport within them (Kain 2004). The convective parameterization is only turned on in the domains with 36-, 12-, and 4-km horizontal resolution. Nudging of winds, temperature, and moisture was performed for the outermost domain following recommendations described in Gilliam and Pleim (2010). Gravity waves and vertical velocity damping at the top of the model domain are used as described in previous work (Loughner et al. 2011; Klemp et al. 2008; Skamarock et al. 2008).

\section{b. Air-quality model description}

The CMAQ model is used to investigate how the bay breeze influences pollutant transport and the formation of ozone. Here, the model is run with the following user options: 1) the Carbon Bond-05 (CB05) gas-phase chemical mechanism (Yarwood et al. 2005), 2) CMAQ's fifth-generation modal aerosol model (aero5), 3) ACM2 for calculating vertical diffusion, 4) the Asymmetric Convective Model (ACM; Pleim and Chang 1992) for computing convective mixing and containing the heterogeneous chemistry scheme in CMAQ, and 5) the Models-3 Dry Deposition (M3DRY) scheme for calculating dry deposition (Pleim et al. 2001). Chemical initial and boundary conditions come from a Model for Ozone and Related Chemical Tracers, version 4 (MOZART-4), simulation (Emmons et al. 2010). CMAQ model output is saved as hourly averages. The emissions used in the CMAQ simulation are described in the appendix.

\section{Observations}

Surface meteorological and trace-gas surface observations are used to assess the impact of the bay breeze on surface air quality. Both 2-m temperature and 10-m wind speeds were observed by the National Weather Service, and surface ozone concentrations were measured by the Maryland Department of the Environment, District of Columbia Department of the Environment, Virginia Department of Environmental Quality, and Delaware Department of Natural Resources and the Environment. Ship observations were made on board the National Oceanic and Atmospheric Administration (NOAA) Small Research Vessel R8501 (SRVx; NOAA Marine Sanctuaries Program) as part of the GeoCAPECBODAQ field campaign. The ship was equipped with a Thermo Environmental Instruments, Inc., model $49 \mathrm{UV}$ photometric ozone $\left(\mathrm{O}_{3}\right)$ analyzer. The model $49 \mathrm{O}_{3}$ analyzer determines ambient concentration by measuring the attenuation of UV radiation at $254 \mathrm{~nm}$. 
One-minute-average $\mathrm{O}_{3}$ measurements have a 2-sigma (std dev) error of $0.8 \mathrm{ppbv}$. In addition, an $\mathrm{NO}_{y}$ [reactive, odd nitrogen: nitric oxide $(\mathrm{NO})$, nitrogen dioxide $\left(\mathrm{NO}_{2}\right)$ $\left(\mathrm{NO}+\mathrm{NO}_{2}=\mathrm{NO}_{x}\right)$, and the compounds produced from oxidation of $\mathrm{NO}_{x}$, such as nitric acid] detector, described in Luke et al. (1992), was used on the ship. The $\mathrm{NO}_{y}$ detector was calibrated using a standard reference material (SRM) of n-proly nitrate in the laboratory as well as an $\mathrm{NO}_{2}$ SRM during an in situ calibration. The uncertainty of $\mathrm{NO}_{y}$ conversion to $\mathrm{NO}$ using a molybdenum converter heated to $350^{\circ} \mathrm{C}$, as performed here, is on the order of $15 \%$ (Fehsenfeld et al. 1987).

In situ aircraft observations of $\mathrm{O}_{3}, \mathrm{NO}_{y}$, and carbon monoxide $(\mathrm{CO})$ made on board the NASA P3-B are used to interpret the three-dimensional structure of the air pollutants in the atmosphere. Ozone, along with reactive nitrogen, is measured with a four-channel chemiluminescence instrument with one channel for each of $\mathrm{NO}, \mathrm{NO}_{2}, \mathrm{NO}_{y}$, and $\mathrm{O}_{3}$. The $\mathrm{NO}$ is measured by adding reagent $\mathrm{O}_{3}$ to the sample flow stream, producing excited $\mathrm{NO}_{2}$, which emits photons in front of a dry-icecooled photomultiplier tube. Photons are counted to provide the fundamental signal. $\mathrm{NO}_{2}$ is measured in a separate channel via photolytic conversion to $\mathrm{NO}$ using 400-nm light-emitting diodes, followed by detection as NO. In a similar way, $\mathrm{NO}_{y}$ is measured via catalytic conversion of reactive nitrogen species to $\mathrm{NO}$ through reaction with $\mathrm{CO}$ on a solid gold surface heated to $300^{\circ} \mathrm{C}$. Ozone is measured using the same reaction by the addition of reagent $\mathrm{NO}$ to the sample flow. The 1-s detection limit for NO is 10 pptv. It is 15 pptv for $\mathrm{NO}_{2}$ and $\mathrm{NO}_{y}$ and $0.1 \mathrm{ppbv}$ for $\mathrm{O}_{3}$. At high mixing ratios, the overall uncertainty for $\mathrm{NO}$ and $\mathrm{NO}_{2}$ is $10 \%$, and it is $5 \%$ for $\mathrm{O}_{3}$.

The $\mathrm{CO}$, along with methane $\left(\mathrm{CH}_{4}\right)$ and nitrous oxide $\left(\mathrm{N}_{2} \mathrm{O}\right)$, is measured in situ using a three-channel tunable diode laser absorption instrument known as "DACOM" (Sachse 1987, 1988). Dried ambient air is drawn continuously through a low-pressure multipass optical cell where near-infrared diode laser beams measure concentrations using line-locked wavelength modulation spectroscopy. Accuracy is maintained through frequent introduction of calibration gases whose concentrations are determined separately by the appropriate groups at the NOAA Earth Systems Research Laboratory/Global Monitoring Division. Data are reported at one sample per second. The CO observations have a precision of $1 \mathrm{ppbv}$ and an uncertainty of $1.5 \%$.

\section{Results}

Here, we discuss how a bay breeze affected surface air quality and pollutant transport within and between the
PBL and the free troposphere on 11 July 2011 using observations and model results from the $1.33-\mathrm{km}-$ horizontal-resolution domain. Prior to the start of the bay breeze, overnight and early-morning winds were from the south, transporting pollutants over Washington and Baltimore, northward into Pennsylvania (Fig. 2). The southerly winds prevented surface air pollution over the Washington-Baltimore urban corridor from being advected over the Chesapeake Bay. Both observations and model calculations showed that the bay-breeze event began early on 11 July along the western coastline of the Chesapeake Bay. By 1100 eastern daylight time (EDT), a strong virtual potential temperature gradient along the western coastline of the bay initiated this change in wind direction and the bay breeze began to form (Fig. 2). We point out the virtual potential temperature gradient, which is a proxy for the density gradient that drives the bay-breeze circulation. The bay breeze persisted and grew in strength throughout the day. The observations and WRF model simulation show that the bay-breeze convergence zone penetrated inland into the urban corridor, with strong surface convergence present by late afternoon (Fig. 2). A vertical cross section of virtual potential temperature and wind velocities at 1400 EDT shows winds converging and upward vertical motion at the bay-breeze convergence zone near Padonia, Maryland (Fig. 3).

The model simulation for 11 July is compared with ground-, aircraft-, and ship-based observations. Modeled and observed ozone are compared by calculating mean bias, normalized mean bias, root-mean-square error, and normalized mean error, as defined by Eder and $\mathrm{Yu}$ (2006) for maximum 8-h average at groundbased monitoring sites, 15 -s-average data observed by the NASA P-3B below $5 \mathrm{~km}$ AGL, and hourly-average data measured on board the ship (Table 1). The ozonemodel bias can partially be explained by uncertainties in the emissions and chemistry in the model. The model overestimated $\mathrm{NO}_{y}$ concentrations, suggesting emissions are too high (Anderson et al. 2014, manuscript submitted to Atmos. Environ.). Modeled $\mathrm{NO}_{y}$ concentrations were $25 \%$ larger than ship-observed concentrations and 288\% larger than NASA P-3B aircraft observations on 11 July. The CMAQ model overestimated $\mathrm{NO}_{y}$ concentrations in comparison with ship observations during most of the days of the CBODAQ field campaign (Goldberg et al. 2014). The overestimation of $\mathrm{NO}_{y}$ over other U.S. cities has been seen during other modeling studies as well (Brioude et al. 2013; Yu et al. 2012). The positive bias in $\mathrm{NO}_{y}$ is also explained by uncertainties in conversion rates of $\mathrm{NO}_{z}$ (i.e., $\mathrm{NO}_{y}-\mathrm{NO}_{x}$ ) to $\mathrm{NO}_{2}$ within the $\mathrm{CB} 05$ chemical mechanism used in CMAQ as described by Goldberg 

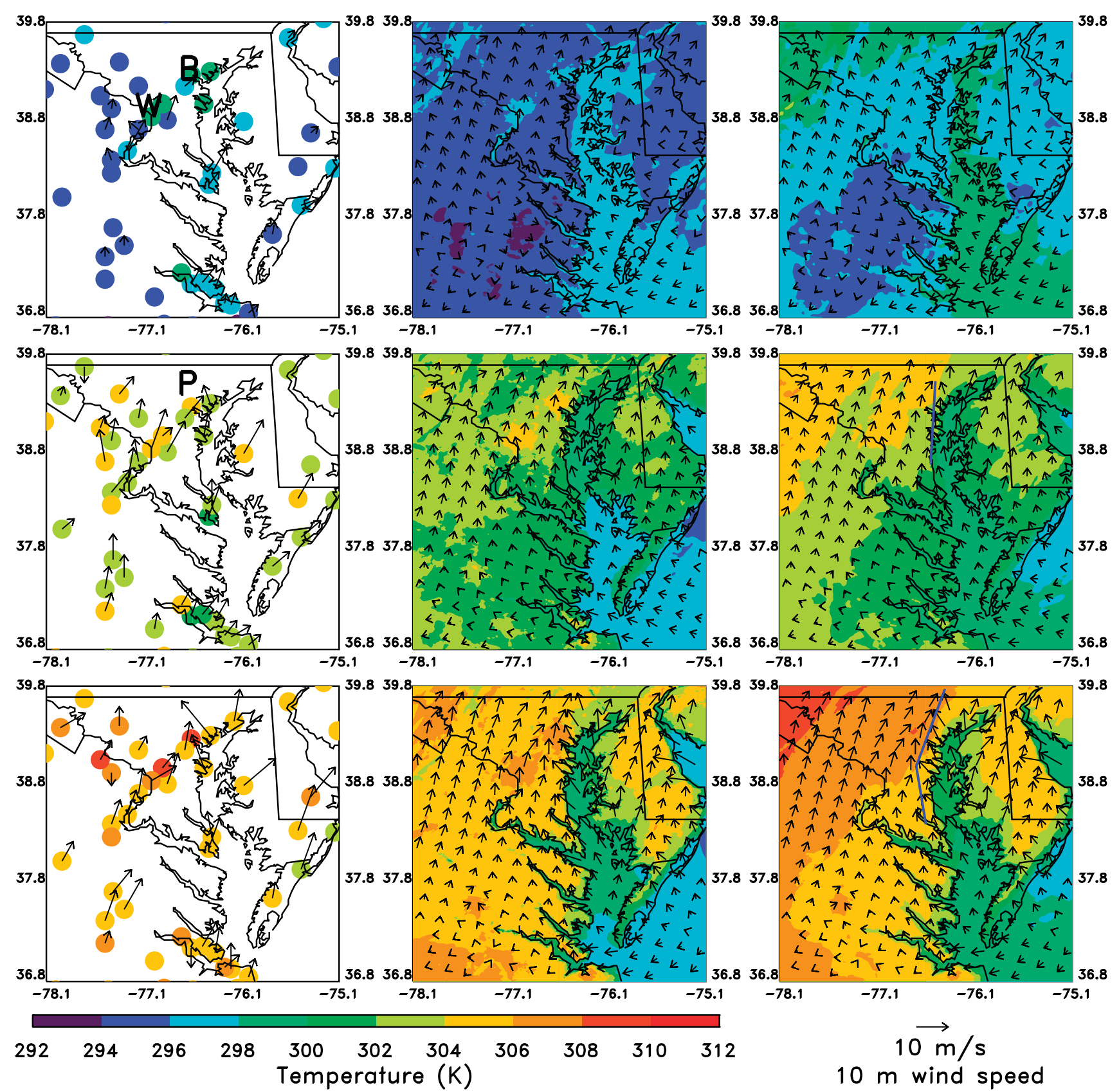

FIG. 2. (left) Observed 2-m temperature and 10-m wind velocity, (center) WRF-diagnosed 2-m temperature and 10-m wind velocity, and (right) WRF-simulated virtual potential temperature in the first model layer (about $11 \mathrm{~m}$ AGL) and 10-m wind velocity on $11 \mathrm{Jul} 2011$ at (top) 0700, (middle) 1100, and (bottom) 1400 EDT. The WRF results are from the $1.33-\mathrm{km}$-horizontal-resolution domain. One of every 14 grid cells has a wind vector plotted. The bay-breeze circulation along the northern half of the western coastline of the bay began to form at 1100 EDT when winds over the water changed from calm or southwesterly to south-southeasterly while winds over land remained southerly or south-southwesterly (see middle row). The bay-breeze convergence zone pushed farther inland by 1400 EDT (see bottom row). The letters $\mathrm{W}$ and $\mathrm{B}$ in the top-left panel show the locations of Washington and Baltimore, respectively, and the letter P in the middle-left panel denotes the location of Padonia. The blue lines in the middle-right and bottom-right panels show the location of the baybreeze front. The bay breeze was identified by noting the change in surface wind direction associated with the large virtual potential temperature gradient, surface convergence, and vertical motion at the bay-breeze front, as shown in Fig. 3, below.

et al. (2014). We focus on the role of the bay breeze in transporting air pollutants out of the boundary layer as shown in the $\mathrm{P}-3 \mathrm{~B}$ observations and the model simulation (see below).
Observations from ground-based monitoring sensors showed localized areas of high values of maximum 8-h-average surface ozone concentrations near the bay-breeze convergence zone, which was within the 


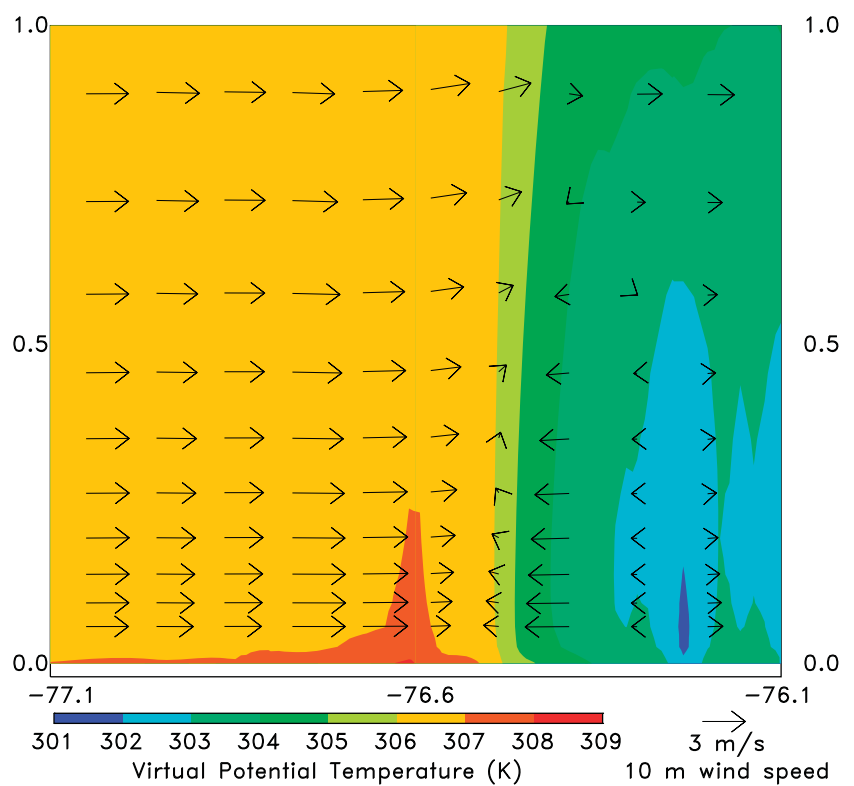

FIG. 3. Vertical cross section of virtual potential temperature and explicit wind velocities at 1400 EDT in the lowest $1 \mathrm{~km}$ between $77.1^{\circ}$ and $76.1^{\circ} \mathrm{W}$ at $39.46^{\circ} \mathrm{N}$. One of every six grid cells in the horizontal direction has a wind vector plotted. This cross section passes through Padonia, which is located at $39.46^{\circ} \mathrm{N}, 76.63^{\circ} \mathrm{W}$.

Washington-Baltimore metropolitan area (Fig. 4). As the bay-breeze convergence front penetrated within the urban corridor, the surface winds caused urban emissions on both sides of the bay-breeze front to converge. Farther away from the convergence zone, cleaner air over the water and over rural and suburban areas penetrated into urban areas, resulting in a large horizontal gradient in ozone concentrations with the highest concentrations located near the bay-breeze convergence zone in the urban corridor. The model positive bias in ozone (Fig. 4) is due to uncertainties in the emissions and chemistry as discussed above and in Goldberg et al. (2014).

The southerly winds prevented pollutants from Washington and Baltimore from being transported over the bay during the overnight and early-morning hours prior to the development of the bay breeze (Fig. 2), preventing higher surface ozone concentrations over the Chesapeake Bay than over the adjacent land (Fig. 4). The locations of the ship throughout 11 July as part of the GeoCAPE-CBODAQ field campaign are shown in Fig. 5. The model positive bias exists over water (Fig. 6) as well as over land (Fig. 4); both model and observations showed lower surface ozone values over the estuarine waters than over the land, however.

The NASA P-3B aircraft performed in situ observations over the region and performed spirals sampling the air in the vertical direction to obtain a three-dimensional view of air-pollution concentrations (Fig. 5). Both the
TABLE 1. The 11 Jul 2011 CMAQ 1.33-km-horizontal-resolutiondomain simulated mean bias (MB), normalized mean bias (NMB), root-mean-square error (RMSE), and normalized mean error (NME), as defined by Eder and $\mathrm{Yu}$ (2006), for maximum 8-h-average $\mathrm{O}_{3}$ at ground-based monitoring sites, 15 -s average $\mathrm{P}-3 \mathrm{~B} \mathrm{O}_{3}$ measurements within and above the PBL, and hourly-average ship $\mathrm{O}_{3}$ observations.

\begin{tabular}{lrccc}
\hline \hline & MB & $\begin{array}{c}\text { NMB } \\
(\%)\end{array}$ & RMSE & $\begin{array}{c}\text { NME } \\
(\%)\end{array}$ \\
\hline Ground sites max 8-h avg & 16.3 & 29.3 & 18.0 & 29.3 \\
P-3B hourly avg within & 9.7 & 12.8 & 16.6 & 16.9 \\
$\quad$ PBL & & & & \\
P-3B hourly avg above & -0.66 & -0.97 & 14.6 & 18.2 \\
$\quad$ PBL & & & & \\
Ship hourly avg & 9.9 & 17.6 & 10.6 & 17.6 \\
\hline
\end{tabular}

model and aircraft observations reveal that ozone concentrations throughout the PBL were highest near the bay-breeze convergence zone near Beltsville (Maryland) and Padonia (Fig. 7). Rapid mixing in the PBL caused high air-pollution concentrations near the surface to be transported throughout the boundary layer. Winds at $850 \mathrm{hPa}$, or about $1.5 \mathrm{~km}$, within the boundary layer near the bay-breeze convergence zone and in the free troposphere downwind of this region were southwesterly (Fig. 8). These upper-level winds transported pollutants near the top of the boundary layer near the bay-breeze convergence zone toward Aldino, Edgewood, Essex, and Fair Hill (all in Maryland), where a lower PBL height was present than in the region of the convergence zone (Fig. 7) because of southerly or southeasterly surface winds from the bay advecting cooler air from the bay over the four observational sites (Fig. 2). Pollution near the top of the boundary layer at the bay-breeze convergence zone was transported downwind where it was horizontally advected out of the PBL and into the free troposphere. High ozone concentrations were observed and simulated in the free troposphere over Aldino, Edgewood, Essex, and Fair Hill (Fig. 7). Note that the bay breeze on this day occurred on the western side of the bay and not the northern end. The northern coastline of the bay experienced offshore winds before and after the bay breeze formed. Areas near the northern coastline of the bay (i.e., Aldino and Edgewood) were affected by the bay breeze aloft, however. The upper levels over this area were downwind of the bay-breeze front, resulting in high air-pollution levels aloft (Fig. 7). In a similar way, comparisons between the NASA P-3B and CMAQ reveal high $\mathrm{CO}$ concentrations at the surface and throughout the boundary layer near the bay-breeze convergence zone and in the free troposphere downwind of the baybreeze convergence zone (Fig. 9). 


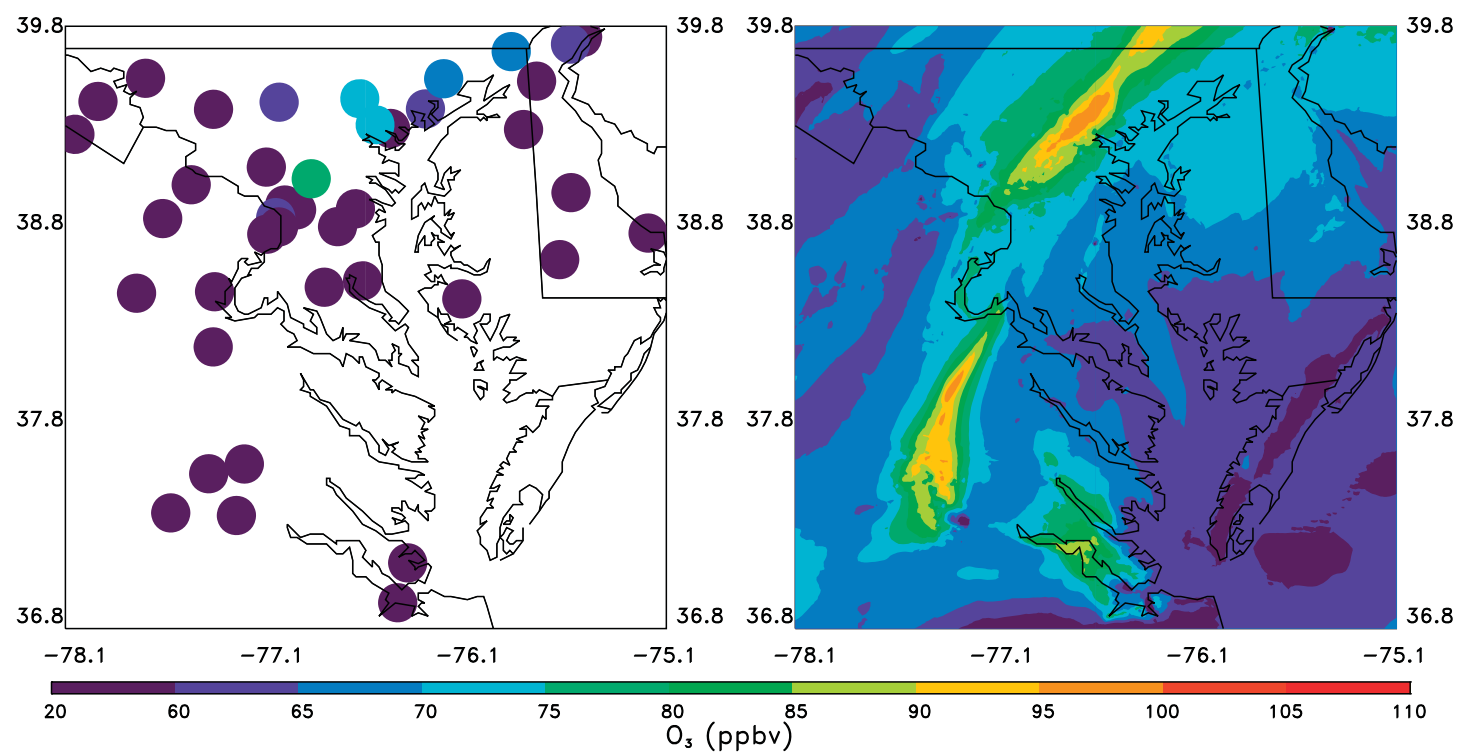

FIG. 4. (left) Observed and (right) CMAQ-simulated maximum surface 8-h-average ozone on 11 Jul 2011. CMAQ results are from the $1.33-\mathrm{km}$-horizontal-resolution domain.

A time series of CMAQ-simulated ozone maps at the surface reveals that the highest surface concentrations in the Washington and Baltimore metropolitan areas were located near the bay-breeze convergence zone after the early formation of the bay breeze (Fig. 10; 12001800 EDT). In addition, ozone maps at about $1.5 \mathrm{~km}$ AGL show that increased ozone concentrations aloft originated near the bay-breeze convergence zone during the early afternoon (Fig. 10; 1400-1800 EDT). The high levels of ozone and its precursors were then transported downwind to the east-northeast. It can be seen that CMAQ simulated high ozone concentrations aloft over areas with low surface ozone concentrations north of the Chesapeake Bay (Fig. 10; model simulations for 1600 and 1800 EDT), which is also shown in CMAQ and P-3B comparisons (Fig. 7).

A back trajectory was calculated to investigate where the high pollution concentrations at $1.5 \mathrm{~km}$ over Edgewood originated, and a forward trajectory was calculated to determine where this plume was transported (Fig. 11). The domain with 4-km horizontal resolution was used because it has more area than the domain with $1.3-\mathrm{km}$ horizontal resolution yet the resolution was high enough to capture the local-scale bay-breeze circulation. Kinematic three-dimensional backward and forward trajectories from Edgewood initialized at $1.5 \mathrm{~km}$ AGL at 1600 EDT show that the air parcels originated in the boundary layer west of the baybreeze front at 1400 EDT, traveled northeast over Edgewood at 1600 EDT above the PBL, and entered southern New England by 0200 EDT the next day (Fig. 11). The trajectory exited the 4-km domain after
0300 EDT. Cross sections of ozone and carbon monoxide along the trajectories show high pollutant concentrations throughout the boundary layer between 1400 and 1500 EDT, which was when the back-trajectory path was within the boundary layer near the bay-breeze front (Figs. 12 and 13). The cross sections show increased pollution aloft (from $500 \mathrm{~m}$ to $2 \mathrm{~km}$ in altitude) from

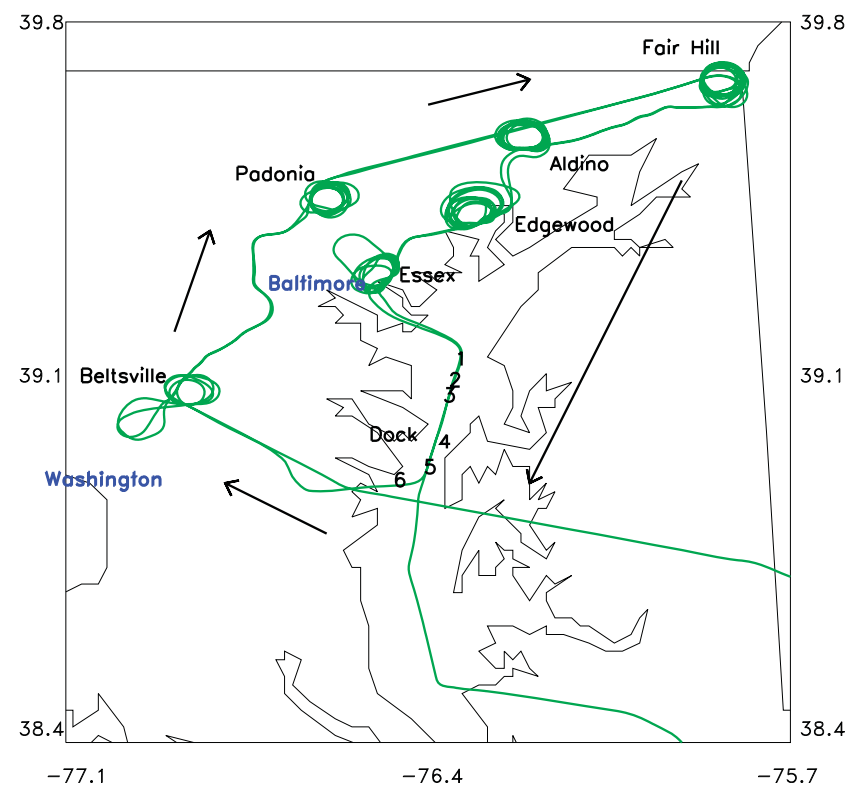

FIG. 5. Map showing the location of the ship dock and the six stations (1-6) to which it went on 11 Jul 2011. Also shown is the flight path of the NASA P-3B on 11 Jul 2011, the locations where the plane spiraled over monitoring sites, and the location of Washington and Baltimore. The P-3B made two clockwise circuits, as depicted by the arrows. 


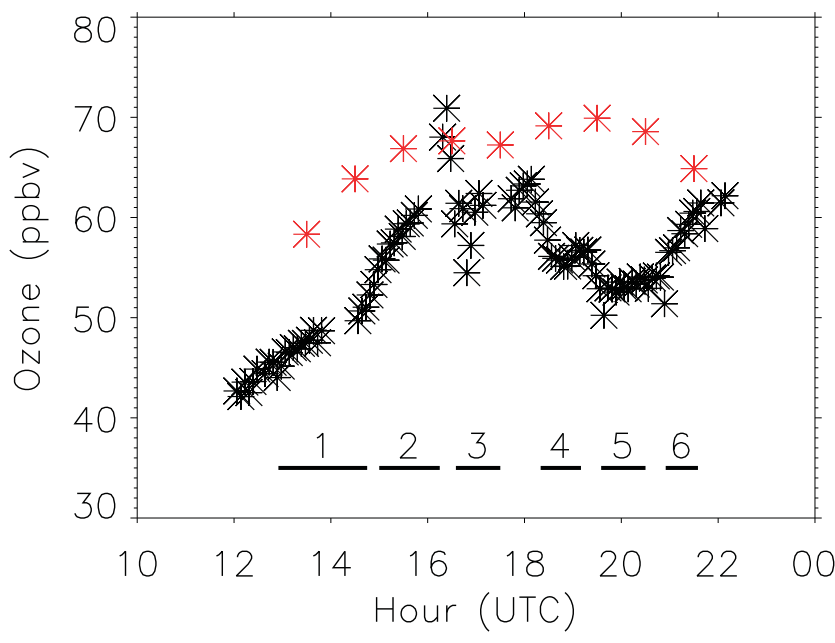

FIG. 6. Observed (black) and CMAQ-simulated (red) surface ozone concentrations from the ship on the Chesapeake Bay on 11 Jul 2011. The black lines and the numbers 1-6 depict when the ship was at each of the six stations shown in Fig. 5. CMAQ results are from the 1.33-km-horizontal-resolution domain.

1600 to 0300 EDT, which was when the trajectory was downwind of the bay-breeze convergence zone in the free troposphere (Figs. 12 and 13). Peak $\mathrm{O}_{3}$ and $\mathrm{CO}$ mixing ratios descended in altitude overnight to $\sim 1 \mathrm{~km}$, making it likely that this plume mixed down to the surface as the boundary layer grew in depth on 12 July outside the area of the 4-km domain, affecting surface air quality in New England.

\section{Discussion}

We demonstrated how a bay breeze caused locally high surface ozone concentrations on 11 July 2011 in Maryland. The bay-breeze convergence zone located within the Washington-Baltimore metropolitan area caused high air-pollution concentrations on both sides of the bay-breeze front to converge. Cleaner surface air over the water and over rural and suburban areas was transported toward the bay-breeze convergence zone, which resulted in a large horizontal gradient in ozone concentrations. The highest observed maximum 8-haverage ozone reached $75 \mathrm{ppbv}$ at the bay-breeze convergence zone in Beltsville.

A key ingredient in exacerbating air-pollution levels further that was missing in this case was the recirculation of air pollutants as described by Loughner et al. (2011) and summarized here. When synoptic-scale surface winds are westerly, the wind direction over the water must change almost $180^{\circ}$ for a bay breeze to impact the western shore of the Chesapeake Bay. Offshore winds transport pollutants over land across the coastline out over the bay waters. As the winds reverse directions over the water, stagnant conditions ensue, resulting in

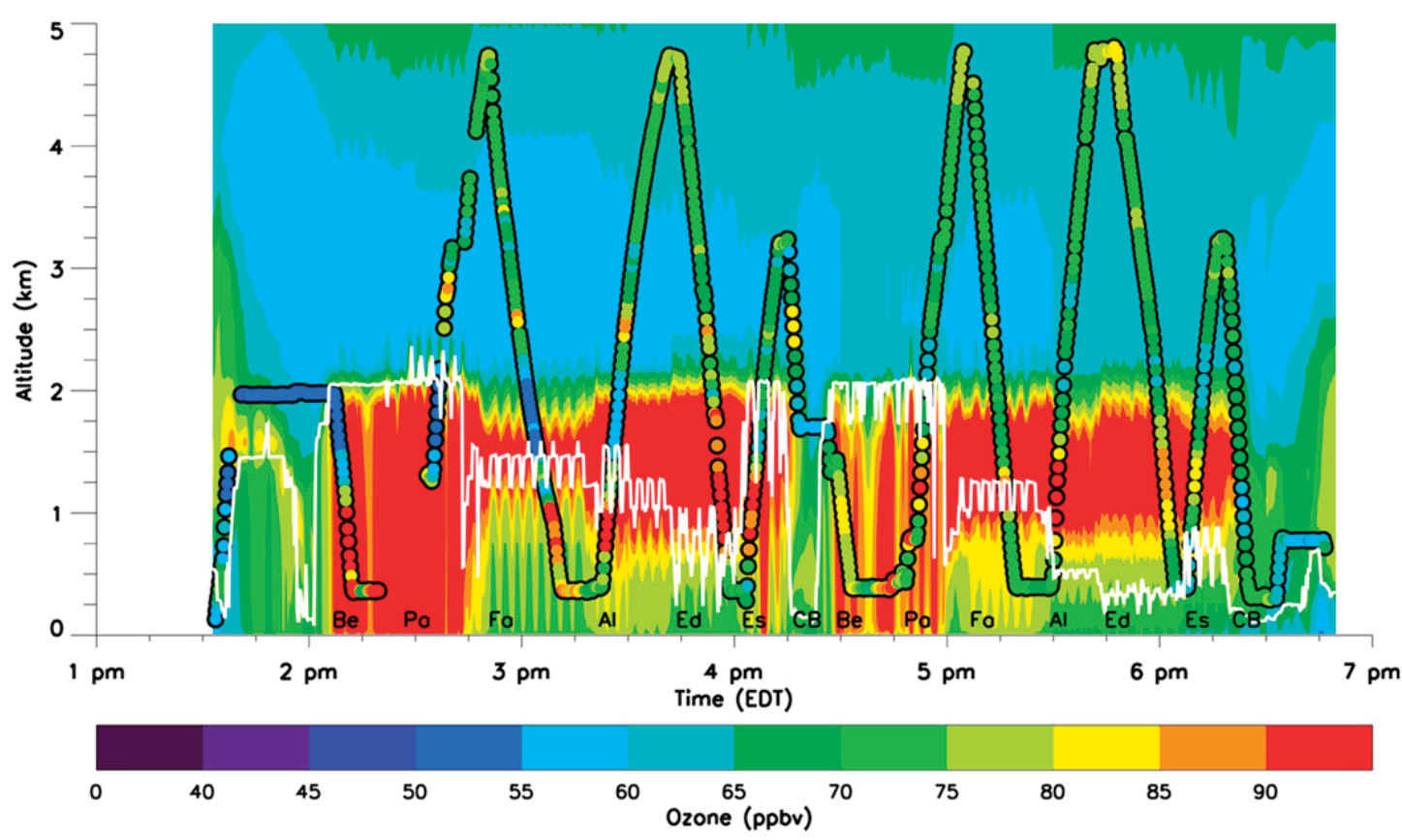

FIG. 7. CMAQ simulated (background) and observed (overlay) ozone concentrations along a flight track on 11 Jul 2011. The white line shows the location of the top of the boundary layer as calculated by the WRF model. The black letters at the bottom of the figure-Be, $\mathrm{Pa}, \mathrm{Fa}, \mathrm{Al}, \mathrm{Ed}, \mathrm{Es}$, and $\mathrm{CB}-$ stand for the spiral locations over Beltsville, Padonia, Fair Hill, Aldino, Edgewood, Essex, and the Chesapeake Bay, respectively. CMAQ results are from the $1.33-\mathrm{km}$-horizontal-resolution domain. 


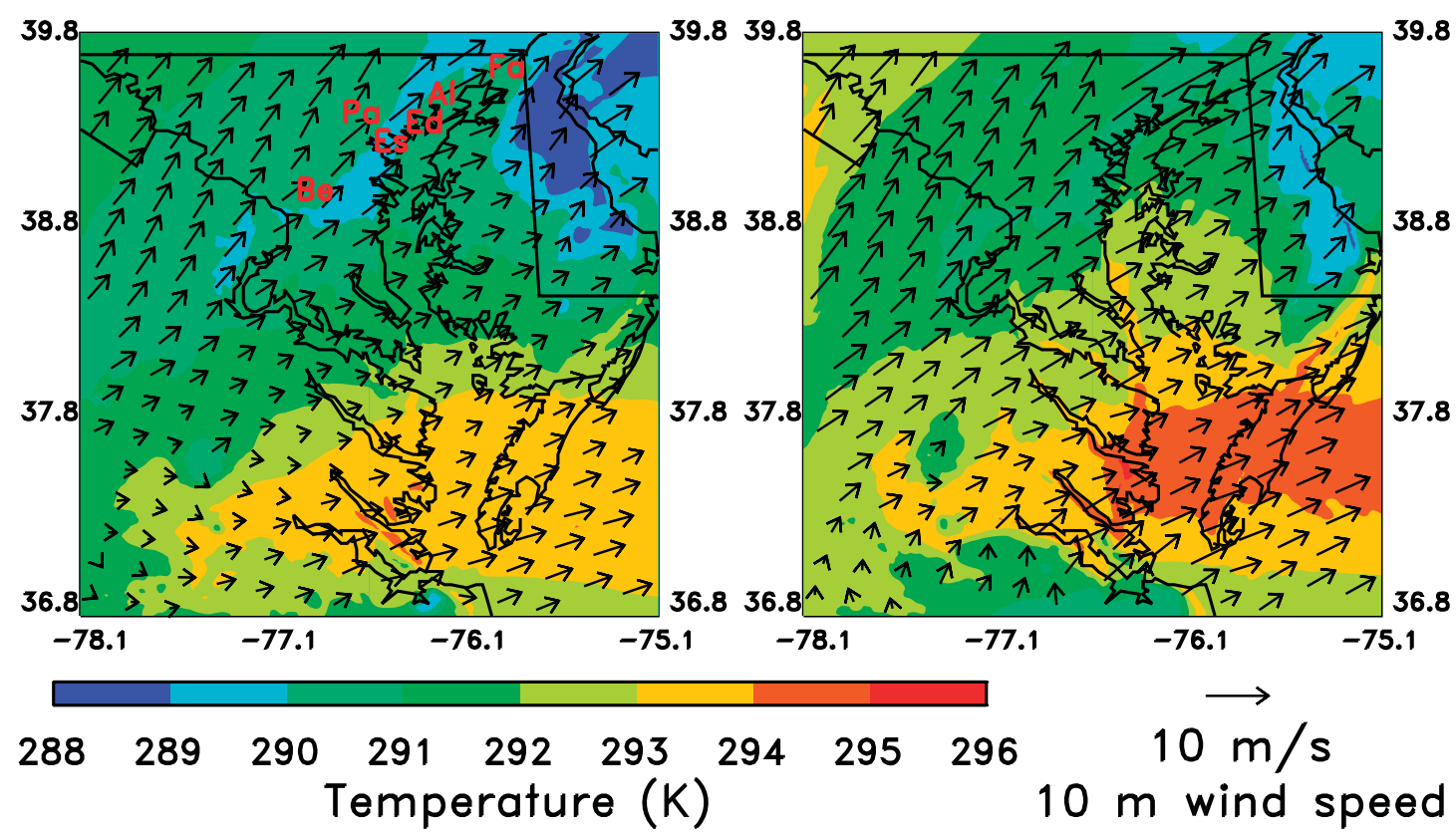

FIG. 8. WRF temperature and wind velocities at $850 \mathrm{hPa}$, which is at an altitude of about $1.5 \mathrm{~km}$, at (left) 1400 and (right) 1600 EDT. WRF results are from the 1.33-km-horizontal-resolution domain. One of every 14 grid cells has a wind vector plotted. The red letters in the left panel-Be, $\mathrm{Pa}, \mathrm{Fa}, \mathrm{Al}, \mathrm{Ed}$, and Es-stand for the spiral locations over Beltsville, Padonia, Fair Hill, Aldino, Edgewood, and Essex, respectively.

pollutants accumulating over the water. After the bay breeze forms, the local-scale winds transport the pollutants over the bay back inland to the convergence zone where they converge with freshly emitted pollutants over land. On 11 July 2011, however, the synoptic-scale winds were parallel to the western coastline of the bay.
Southerly winds during the overnight and early-morning hours prevented surface air pollution in the Washington and Baltimore metropolitan area from being transported across the coastline prior to the onset of the bay breeze.

The southerly winds on 11 July played a role in the formation and strength of the bay breeze. The onset of

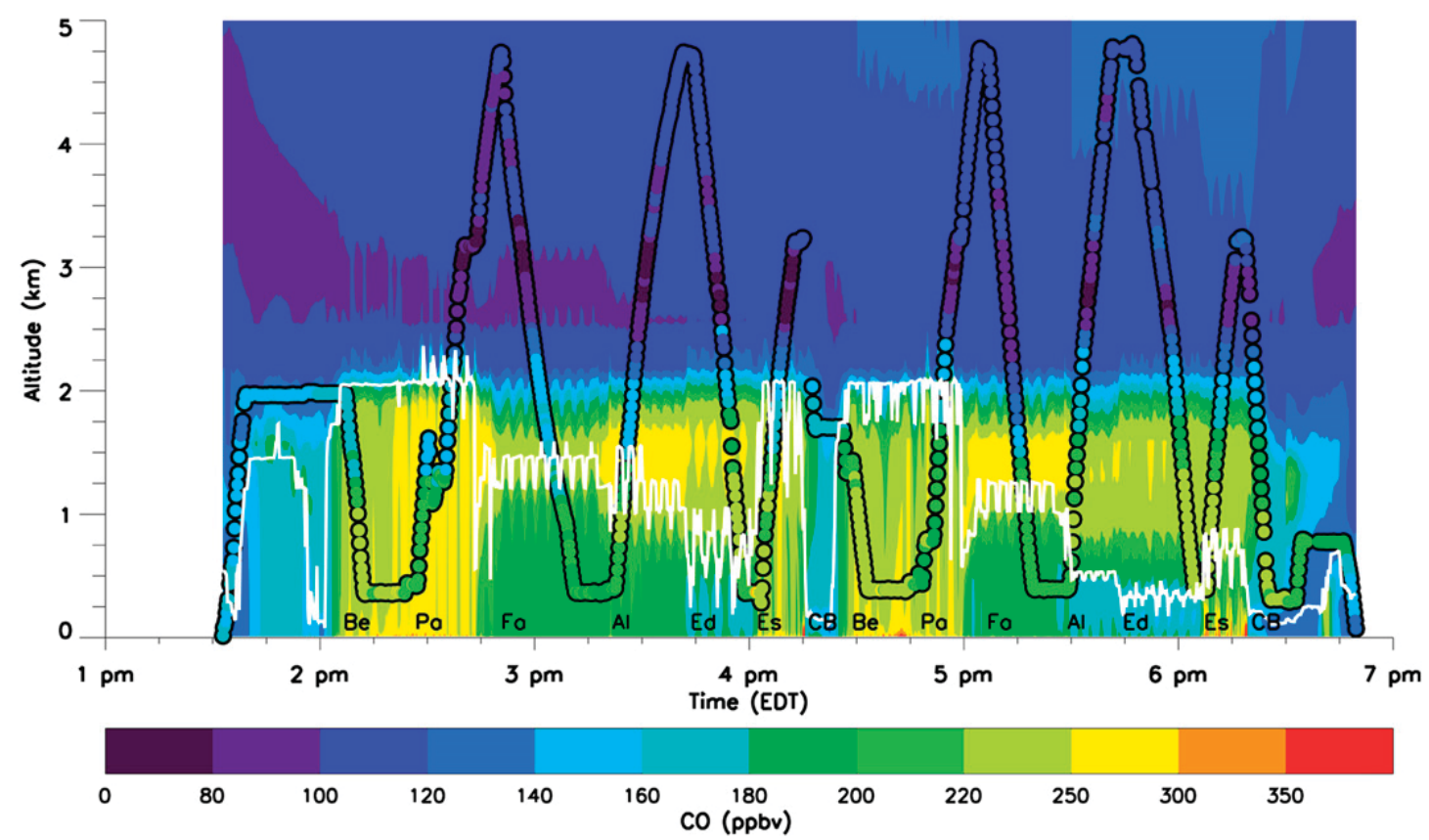

FIG. 9. As in Fig. 7, but for carbon monoxide. 

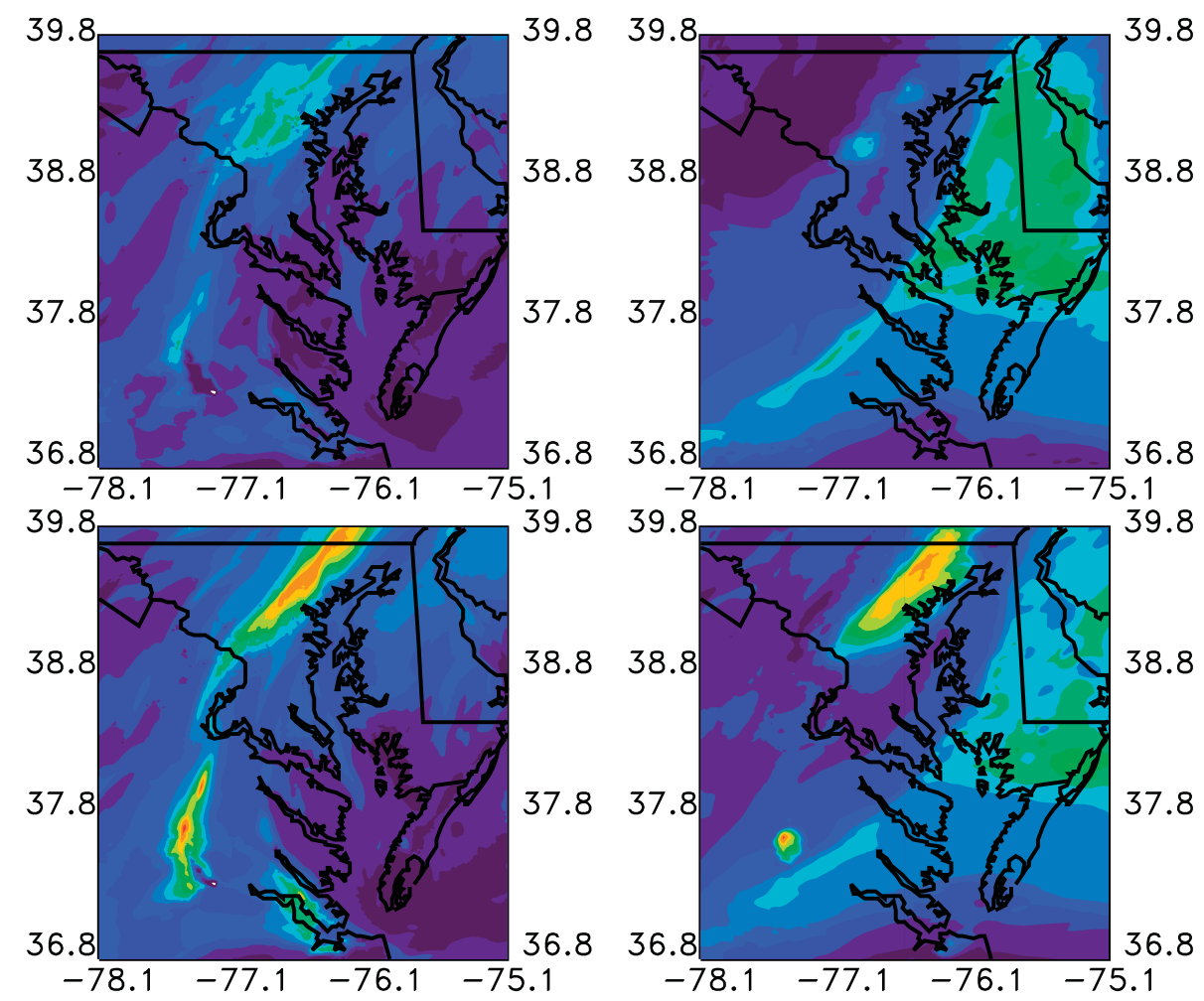

39.8
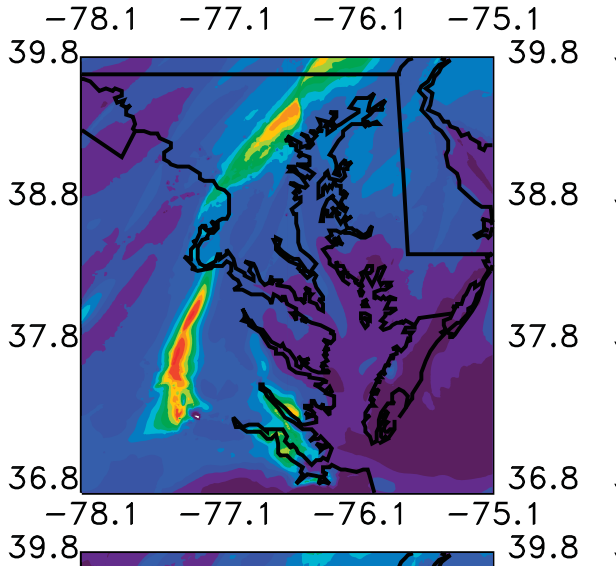

36.8

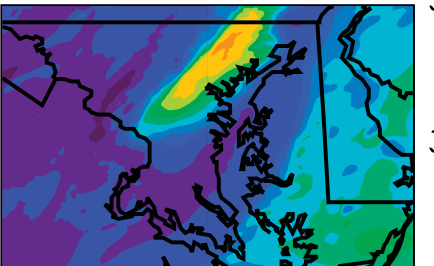

38.8

39.8

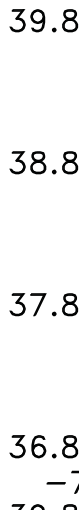

$\begin{array}{llll}-78.1 & -77.1 & -76.1 & -75\end{array}$

36.8

39.8

37.8

37.8

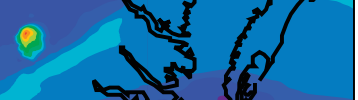

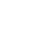
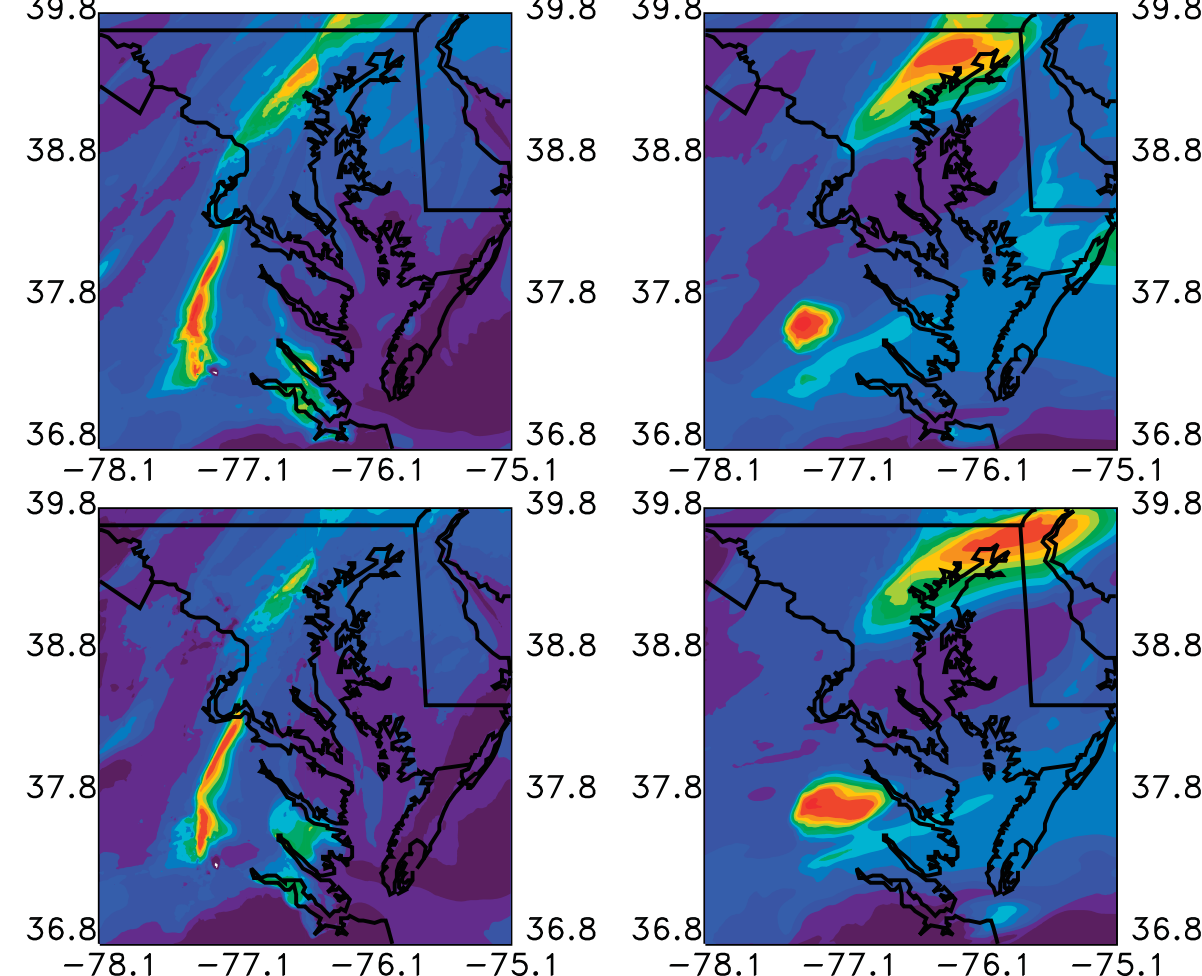

39.8

39.8

38.8
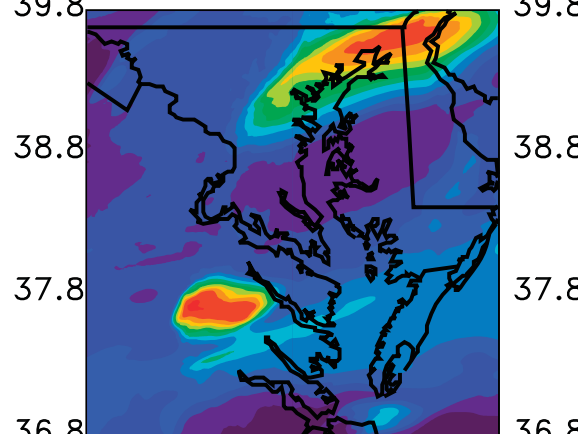

38.8

$37.8 \quad 37.8$

$36.8 \quad 36.8$
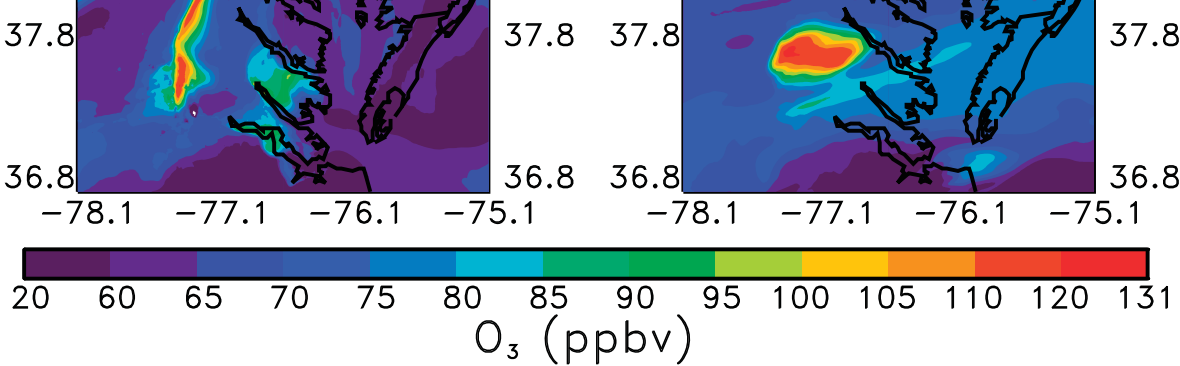

FIG. 10. CMAQ-simulated ozone concentrations (left) at the surface and (right) at $\sim 1.57 \mathrm{~km}$ AGL at (top) 1200, (top middle) 1400, (bottom middle) 1600, and (bottom) 1800 EDT from the $1.33-\mathrm{km}$-horizontal-resolution domain. 


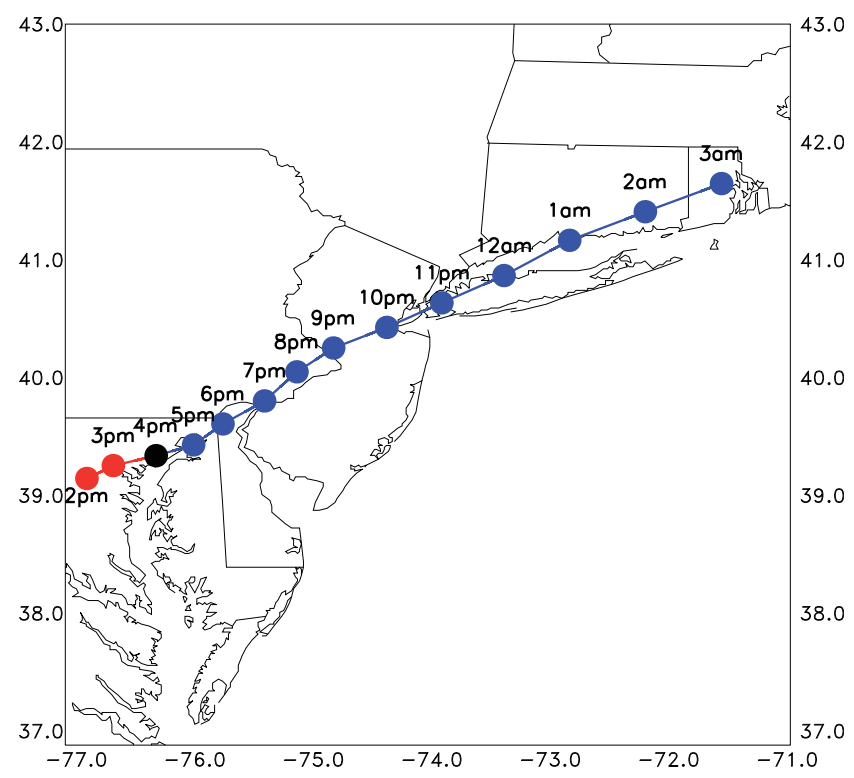

FIG. 11. Horizontal path of a back trajectory from $1.5 \mathrm{~km}$ AGL over Edgewood (black) from 1600 to 1400 EDT (red) and a forward trajectory from $1.5 \mathrm{~km}$ AGL over Edgewood from 1600 to 0200 EDT (blue) using the 4-km-horizontal-resolution WRF simulation.

a bay-breeze circulation begins earlier, when the synoptic-scale winds are parallel to the coastline with land to the left (lower pressure over land), which is called a "corkscrew" bay breeze, as described in detail by Steele et al. (2013) and summarized here. This was the case on 11 July along the western shore of the Chesapeake Bay. A corkscrew bay breeze can be pictured as winds following the coastline in a corkscrew pattern with rising air over land and sinking air over water. Prior to the corkscrew bay breezes forming, stronger surface friction over land than over water results in divergence and descending motion at the coastline. This descending motion helps to initiate the bay-breeze circulation, allowing the local-scale circulation to form earlier, with a weaker surface virtual potential temperature gradient, and under stronger early-morning winds than if the synoptic-scale winds were offshore. Likewise, if the synoptic-scale winds were parallel to the coastline with the land to the right (higher pressure over land), as on the eastern shore of the Chesapeake Bay on 11 July, differences in surface friction in the early morning would cause convergence and rising motion at the coastline, which would make it more difficult for a bay breeze to develop (Steele et al. 2013). A bay breeze that forms under these conditions is called a backdoor bay breeze, and it would be weaker and form later in the day than corkscrew bay breezes under similar wind speeds and virtual potential temperature gradients (Steele et al. 2013). As opposed to other bay-breeze events, corkscrew bay-breeze events do not magnify the trace-gas mixing ratios in air-pollution events through recirculation of surface air pollution, but they do amplify the duration of the air-pollution events through prolonged strong surface convergence.

In addition, we see that strong, prolonged bay-breeze events can transport a large amount of air pollution out of the PBL and into the free troposphere. The lifting motion at the sea- and bay-breeze convergence zones

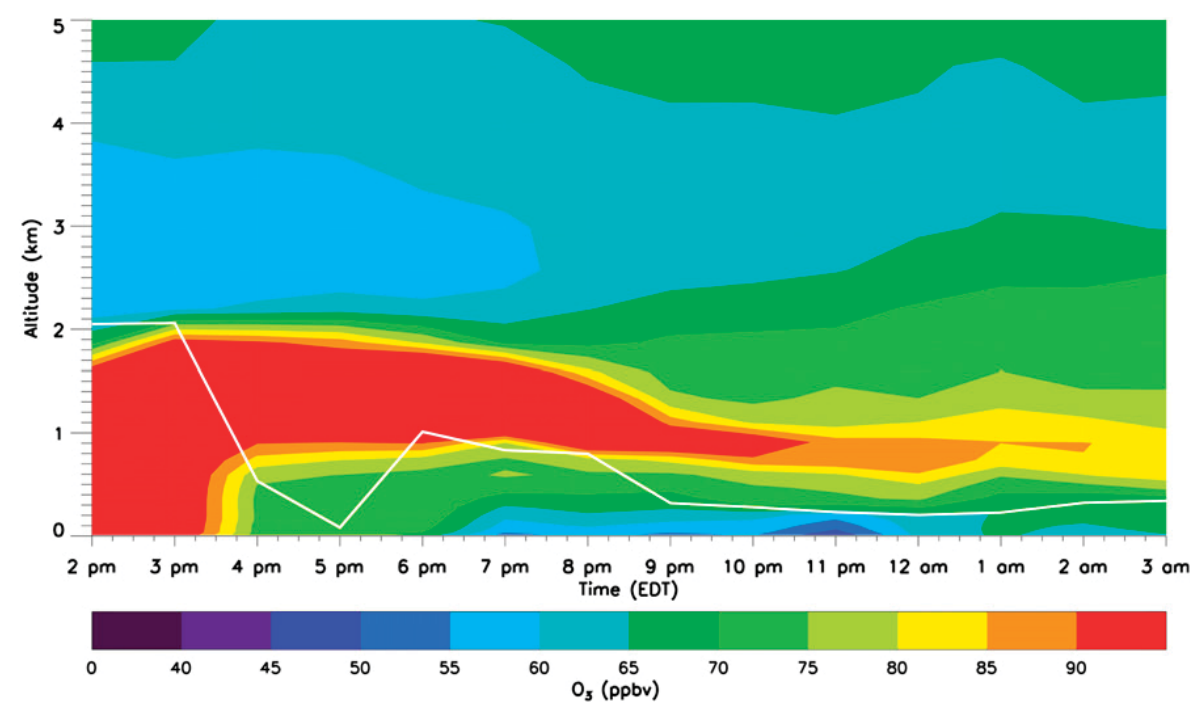

FIG. 12. Vertical cross section of CMAQ-simulated ozone concentrations along the trajectories in Fig. 11 from the 4-km-horizontal-resolution domain. The white line shows the location of the top of the boundary layer as calculated by the WRF model from the 4-km-horizontalresolution domain. 


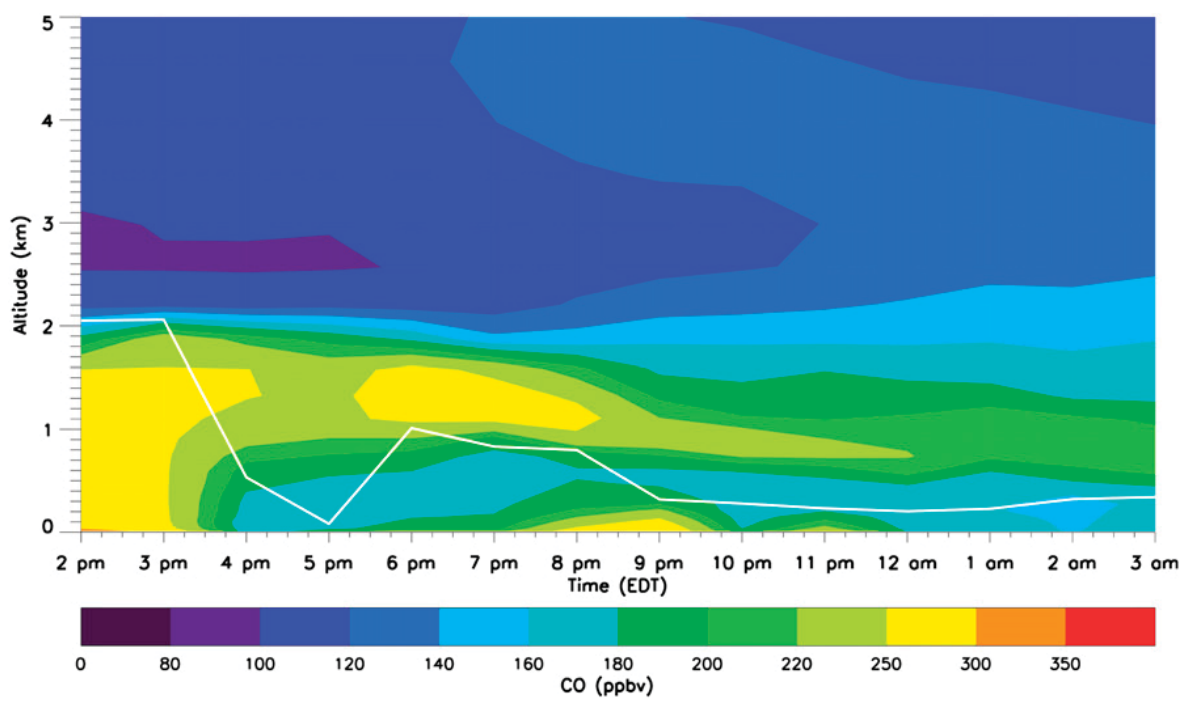

FIG. 13. As in Fig. 12, but for carbon monoxide.

has been shown to initiate thunderstorms and severe weather (Kingsmill 1995), as well as to transport pollutants aloft (Loughner et al. 2011). Little research has been performed to show how bay-breeze circulations affect boundary layer venting. This process is significant in that pollutants transported from the boundary layer to the free troposphere affect air quality farther downwind. Once in the free troposphere, pollutants have longer lifetimes and are susceptible to long-range transport. These pollutants in the free troposphere can eventually be transported back into the PBL and subside to the surface, affecting air quality, human health, and ecosystem processes far away from the pollution source (Cooper et al. 2010). In this study, we show that the pollution layer remained aloft as it traveled into southern New England. We did not determine where this layer eventually reentered the boundary layer and mixed down to the surface to affect air and water quality because it was transported out of our domain.

\section{Conclusions}

In this study, WRF and CMAQ model simulations are analyzed alongside ground-based, aircraft, and shipboard observations to investigate the role of the Chesapeake Bay breeze on surface air quality, pollutant transport, and boundary layer venting. Southerly winds during the overnight and early-morning hours prevented pollutants from the Washington and Baltimore area from being transported out over the surface waters of the Chesapeake Bay. Therefore, the pollutants were not recirculated over the water and then back inland once the bay breeze formed to converge with freshly emitted pollutants over land near the bay-breeze convergence zone. Southerly synoptic-scale winds are, however, favorable for producing a strong corkscrew bay breeze that forms early in the day along the western coastline of the Chesapeake Bay. Results show that a strong and prolonged bay breeze caused locally high surface ozone concentrations near the bay-breeze convergence zone, which penetrated into the urban corridor. The onset of the bay breeze occurred early, by 1100 EDT, resulting in an extended period of convergence of air pollution at the bay-breeze front.

This strong bay-breeze circulation also resulted in a significant amount of air pollution being transported out of the PBL and into the free troposphere, which has implications for regional air quality. Pollutants transported from the PBL to the free troposphere gain a longer lifetime and are susceptible to long-range transport. These pollutants can then subside back into the PBL, having an impact on surface air quality, human health, and ecosystem processes far away from their emissions sources.

Acknowledgments. This work was supported under the NASA Earth Venture-1 DISCOVER-AQ project and NASA Grants NNX10AQ79G and NNX11AP07G. Contributions from Antonio Mannino are gratefully acknowledged.

\section{APPENDIX}

\section{Emissions}

Anthropogenic emissions input files for the CMAQ model are created with the Sparse Matrix Operator Kernel Emissions (SMOKE) modeling system (Houyoux and Vukovich 1999). Because a 2011 emissions inventory 
is not yet available, the closest projected inventory was used. We used a projected 2012 emissions inventory, which is grown from the 2005 National Emissions Inventory (NEI) to include estimated emissions changes due to growth and emissions controls that were to be implemented by 2012 (EPA 2011). Annual projected point and countywide area emissions are temporally distributed on the basis of time of day, day of week, and season using temporal surrogates from the EPA. Mobile emissions estimates from cars, trucks, and motorcycles are computed with the Motor Vehicle Emission Simulator (MOVES; EPA 2012). Point sources are vertically distributed on the basis of the meteorological conditions, stack height, and the temperature and velocity of the emissions exiting the stack. Countywide area emissions are horizontally distributed on the basis of land use from spatial surrogates provided by the EPA for the domains with $36-$ and $12-\mathrm{km}$ horizontal resolution. Spatial surrogates for the 4- and 1.33-km domains are generated from the Multimedia Integrated Modeling System (MIMS) Spatial Allocator (Eyth and Brunk 2005) using data from the 2000 U.S Census, National Land Cover Characteristics Data, and other spatial sources available from EPA's Emissions Modeling Clearinghouse.

Biomass burning emissions are obtained from the Fire Inventory from NCAR, version 1.0 (FINNv1; Wiedinmyer et al. 2011). This inventory estimates biomass-burning emissions with a resolution of $1 \mathrm{~km}$ on the basis of fire hot spots, area burned, land-cover maps, and biomass consumption estimates from Moderate Resolution Imaging Spectroradiometer (MODIS) satellite products (Wiedinmyer et al. 2011). In the ideal case, the emissions would be dispersed in the vertical direction on the basis of the meteorological conditions and the intensity of the fire. A plume-rise algorithm for vertical dispersion of fire emissions in CMAQ has not been developed, however, and therefore the emissions are placed in the lowest level of the model. Plumes of biomass-burning emissions were not observed in the Washington and Baltimore metropolitan area during the time of interest to this study, and therefore placing the fire emissions near the surface did not have any impact on the model results presented here. Airborne observations made on board the NASA P-3B during the DISCOVER-AQ field campaign showed negligible wildfire impact in the region. Measurements of acetonitrile, a tracer for biomass burning, revealed that no smoke plumes were present in the WashingtonBaltimore metropolitan region during July. Observed acetonitrile observations on 11 July were low, with minimum, median, and maximum concentrations of $0.102,0.144$, and $0.198 \mathrm{ppbv}$, respectively. Observed acetonitrile concentrations over the western United
States from long-range transported biomass-burning plumes originating from Asia have been observed to be $\sim 0.5$ ppbv (de Gouw et al. 2004).

Biogenic and lightning emissions are calculated online within the CMAQ model. The Biogenic Emissions Inventory System (BEIS) calculates biogenic emissions on the basis of the meteorological output from the WRF simulation and land-use data describing the vegetation (Vukovich and Pierce 2002). Lightning $\mathrm{NO}_{x}$ emissions are calculated from lightning-flash count data from the National Lightning Detection Network and convective precipitation as calculated in WRF (Allen et al. 2012). Convective precipitation is calculated within WRF's convective parameterization, and, because no convective parameterization is turned on in the finest horizontal domain (1.33-km resolution), the lightning emissions from the $4-\mathrm{km}$ domain are used in the $1.33-\mathrm{km}$ domain. This method may result in the placement of lightning emissions in areas where deep convection is not located in the $1.33-\mathrm{km}$ domain since parameterized convection in the 4-km domain and resolved convection in the $1.33-\mathrm{km}$ domain could behave differently. Misplaced lightning emissions do not affect the results during the 11 July bay-breeze scenario discussed in this paper, however. No lightning emissions are placed in the $1.33-\mathrm{km}$ domain on 10 and 11 July. The area of the $1.33-\mathrm{km}$ domain is small, and so the effects of lightning emissions placed in the $1.33-\mathrm{km}$ domain on 9 July were transported well out of the area of interest. Therefore, the only lightning emissions affecting the $1.33-\mathrm{km}$ domain, if any, during the 11 July case study presented in our paper are emissions calculated online in the outer domains that are transported into the innermost domain.

\section{REFERENCES}

Allen, D. J., K. E. Pickering, R. W. Pinder, B. H. Henderson, K. W. Appel, and A. Prados, 2012: Impact of lightning-NO on eastern United States photochemistry during the summer of 2006 as determined using the CMAQ model. Atmos. Chem. Phys., 12, 1737-1758, doi:10.5194/acp-12-1737-2012.

Angevine, W. M., and Coauthors, 2004: Coastal boundary layer influence on pollutant transport in New England. J. Appl. Meteor., 43, 1425-1437, doi:10.1175/JAM2148.1.

Banta, R. M., and Coauthors, 2005: A bad air day in Houston. Bull. Amer. Meteor. Soc., 86, 657-669, doi:10.1175/BAMS-86-5-657.

Booker, F., and Coauthors, 2009: The ozone component of global change: Potential effects on agricultural and horticultural plant yield, product quality and interactions with invasive species. J. Integr. Plant Biol., 51, 337-351, doi:10.1111/ j.1744-7909.2008.00805.x.

Boucouvala, D., and R. Bornstein, 2003: Analysis of transport patterns during an SCOS97-NARSTO episode. Atmos. Environ., 37 (Suppl. 2), 73-94, doi:10.1016/S1352-2310(03)00383-2.

Brioude, J., and Coauthors, 2013: Top-down estimate of surface flux in the Los Angeles Basin using a mesoscale inverse modeling technique: Assessing anthropogenic emissions of 
$\mathrm{CO}, \mathrm{NO}_{x}$, and $\mathrm{CO}_{2}$ and their impacts. Atmos. Chem. Phys., 13, 3661-3677, doi:10.5194/acp-13-3661-2013.

Byun, D., and K. L. Schere, 2006: Review of the governing equations, computational algorithms, and other components of the Models-3 Community Multiscale Air Quality (CMAQ) modeling system. Appl. Mech. Rev., 59, 51-77, doi:10.1115/ 1.2128636.

Cooper, O. R., and Coauthors, 2010: Increasing springtime ozone mixing ratios in the free troposphere over western North America. Nature, 463, 344-348, doi:10.1038/nature08708.

Darby, L. S., 2005: Cluster analysis of surface winds in Houston, Texas, and the impact of wind patterns on ozone. J. Appl. Meteor., 44, 1788-1806, doi:10.1175/JAM2320.1.

de Gouw, J. A., and Coauthors, 2004: Chemical composition of air masses transported from Asia to the U.S. west coast during ITCT 2K2: Fossil fuel combustion versus biomass-burning signatures. J. Geophys. Res., 109, D23S20, doi:10.1029/ 2003JD004202.

Dockery, D. W., C. A. Pope, X. Xu, J. D. Spengler, J. H. Ware, M. E. Fay, B. G. Ferris, and F. E. Speizer, 1993: An association between air pollution and mortality in six U.S. cities. N. Engl. J. Med., 329, 1753-1759, doi:10.1056/NEJM199312093292401.

Eder, B., and S. Yu, 2006: A performance evaluation of the 2004 release of Models-3 CMAQ. Atmos. Environ., 40, 4811-4824, doi:10.1016/j.atmosenv.2005.08.045.

Emmons, L. K., and Coauthors, 2010: Description and evaluation of the Model for Ozone and Related chemical Tracers, version 4 (MOZART-4). Geosci. Model Dev., 3, 43-67, doi:10.5194/ gmd-3-43-2010.

EPA, 2011: Emissions inventory final rule TSD. U.S. Environmental Protection Agency Tech. Support Doc. EPA-H1-OAR-20090491,112 pp. [Available online at ftp://ftp.epa.gov/EmisInventory/ 2005v4_2/transportrulefinal_eitsd_28jun2011.pdf.]

_ 2012: User guide for MOVES2010b. U.S. Environmental Protection Agency Tech. Support Doc. EPA-420-B-12-001b, 202 pp. [Available online at http://www.epa.gov/otaq/models/ moves/documents/420b12001b.pdf.]

Evtyugina, M. G., T. Nunes, C. Pio, and C. S. Costa, 2006: Photochemical pollution under sea breeze conditions, during summer, at the Portuguese west coast. Atmos. Environ., 40, 6277-6293, doi:10.1016/j.atmosenv.2006.05.046.

Eyth, A. M., and B. Brunk, 2005: New features in version 3 of the MIMS Spatial Allocator. CMAS Models-3 Users' Conf., Chapel Hill, NC, University of North Carolina at Chapel Hill, Presentation 6.7,23 pp. [Available online at http://cmascenter. org/conference/2005/ppt/6_7.pdf.]

Fehsenfeld, F. C., and Coauthors, 1987: A ground-based intercomparison of $\mathrm{NO}, \mathrm{NO}_{x}$, and $\mathrm{NO}_{y}$ measurement techniques. J. Geophys. Res., 92, 14710-14722, doi:10.1029/JD092iD12p14710.

Fishman, J., V. Ramanathan, P. J. Crutzen, and S. C. Liu, 1979: Tropospheric ozone and climate. Nature, 282, 818-820, doi:10.1038/282818a0

— J. K. Creilson, P. A. Parker, E. A. Ainsworth, G. G. Vining, J. Szarka, F. L. Booker, and X. Xu, 2010: An investigation of widespread ozone damage to the soybean crop in the upper Midwest determined from ground-based and satellite measurements. Atmos. Environ., 44, 2248-2256, doi:10.1016/ j.atmosenv.2010.01.015.

Galloway, J. N., J. D. Aber, J. W. Erisman, S. P. Seitzinger, R. W. Howarth, E. B. Cowling, and B. J. Cosby, 2003: The nitrogen cascade. Bioscience, 53, 341-356, doi:10.1641/ 0006-3568(2003)053[0341:TNC]2.0.CO;2.
Gilliam, R. C., and J. E. Pleim, 2010: Performance assessment of new land surface and planetary boundary layer physics in the WRF-ARW. J. Appl. Meteor. Climatol., 49, 760-774, doi:10.1175/2009JAMC2126.1.

, J. M. Godowitch, and S. T. Rao, 2012: Improving the horizontal transport in the lower troposphere with four dimensional data assimilation. Atmos. Environ., 53, 186-201, doi:10.1016/j.atmosenv.2011.10.064.

Gilliland, A. B., C. Hogrefe, R. W. Pinder, J. M. Godowitch, K. L. Foley, and S. T. Rao, 2008: Dynamic evaluation of regional air quality models: Assessing changes in $\mathrm{O}_{3}$ stemming from changes in emissions and meteorology. Atmos. Environ., 42, 5110-5123, doi:10.1016/j.atmosenv.2008.02.018.

Godowitch, J. M., G. A. Pouliot, and S. T. Rao, 2010: Assessing multiyear changes in modeled and observed urban $\mathrm{NO}_{\mathrm{x}}$ concentrations from a dynamic model evaluation perspective. Atmos. Environ., 44, 2894-2901, doi:10.1016/j.atmosenv.2010.04.040.

Goldberg, D. L., C. P. Loughner, M. Tzortziou, J. W. Stehr, K. E. Pickering, L. T. Marufu, and R. R. Dickerson, 2014: Higher surface ozone concentrations over the Chesapeake Bay than over the adjacent land: Observations and models from the DISCOVER-AQ and CBODAQ campaigns. Atmos. Environ., 84, 9-19, doi:10.1016/j.atmosenv.2013.11.008.

Gonçalves, M., P. Jiménez-Guerrero, and J. M. Baldasano, 2009: Contribution of atmospheric processes affecting the dynamics of air pollution in south-western Europe during a typical summertime photochemical episode. Atmos. Chem. Phys., 9, 849-864, doi:10.5194/acp-9-849-2009.

Grell, G. A., R. Knoche, S. E. Peckham, and S. A. McKeen, 2004: Online versus offline air quality modeling on cloudresolving scales. Geophys. Res. Lett., 31, L16117, doi:10.1029/ 2004GL020175.

Hansen, J., M. Sato, and R. Ruedy, 1997: Radiative forcing and climate response. J. Geophys. Res., 102, 6831-6864, doi:10.1029/ 96JD03436.

Hong, S.-Y., and J.-O. J. Lim, 2006: The WRF single-moment 6-class microphysics scheme (WSM6). J. Korean Meteor. Soc., 42, 129-151.

Houyoux, M. R., and J. M. Vukovich, 1999: Updates to the Sparse Matrix Operator Kernel Emissions (SMOKE) modeling system and integration with Models-3. The Emissions Inventory: Regional Strategies for the Future, Raleigh, NC, Air and Waste Management Association, 11 pp. [Available online at http:// www.ie.unc.edu/cempd/pub_files/awma99_smoke.pdf.]

Im, U., and Coauthors, 2010: Study of a winter PM episode in Istanbul using the high resolution WRF/CMAQ modeling system. Atmos. Environ., 44, 3085-3094, doi:10.1016/ j.atmosenv.2010.05.036.

Jiménez, P., R. Parra, and J. M. Baldasano, 2005: Control of ozone precursors in a complex industrial terrain by using multiscalenested air quality models with fine spatial resolution $\left(1 \mathrm{~km}^{2}\right)$. J. Air Waste Manage. Assoc., 55, 1085-1099, doi:10.1080/ 10473289.2005.10464709.

_ J. Lelieveld, and J. M. Baldasano, 2006: Multiscale modeling of air pollutants dynamics in the northwestern Mediterranean basin during a typical summertime episode. J. Geophys. Res., 111, D18306, doi:10.1029/2005JD006516.

R. Parra, and J. M. Baldasano, 2007: Influence of initial and boundary conditions for ozone modeling in very complex terrains: A case study in the northeastern Iberian Peninsula. Environ. Modell. Software, 22, 1294-1306, doi:10.1016/ j.envsoft.2006.08.004. 
Kain, J. S., 2004: The Kain-Fritsch convective parameterization: An update. J. Appl. Meteor., 43, 170-181, doi:10.1175/ 1520-0450(2004)043<0170:TKCPAU>2.0.CO;2.

Kingsmill, D. E., 1995: Convection initiation associated with a sea-breeze front, a gust front, and their collision. Mon. Wea. Rev., 123, 2913-2933, doi:10.1175/1520-0493(1995)123<2913: CIAWAS $>2.0 . \mathrm{CO} ; 2$

Klemp, J. B., J. Dudhia, and A. D. Hassiotis, 2008: An upper gravity-wave absorbing layer for NWP applications. Mon. Wea. Rev., 136, 3987-4004, doi:10.1175/2008MWR2596.1.

Lee, H. W., H.-J. Choi, S.-H. Lee, Y.-K. Kim, and W.-S. Jung, 2008: The impact of topography and urban building parameterization on the photochemical ozone concentration of Seoul, Korea. Atmos. Environ., 42, 4232-4246, doi:10.1016/ j.atmosenv.2008.01.021.

Loughner, C. P., D. J. Allen, K. E. Pickering, D.-L. Zhang, Y.-X. Shou, and R. R. Dickerson, 2011: Impact of fair-weather cumulus clouds and the Chesapeake Bay breeze on pollutant transport and transformation. Atmos. Environ., 45, 4060-4072, doi:10.1016/j.atmosenv.2011.04.003.

Luke, W. T., R. R. Dickerson, W. F. Ryan, K. E. Pickering, and L. J. Nunnermacker, 1992: Tropospheric chemistry over the lower Great Plains of the United States 2. Trace gas profiles and distributions. J. Geophys. Res., 97, 20 647-20 670, doi:10.1029/ 92JD02127.

Martins, D. K., R. M. Stauffer, A. M. Thompson, T. N. Knepp, and M. Pippin, 2012: Surface ozone at a coastal suburban site in 2009 and 2010: Relationships to chemical and meteorological processes. J. Geophys. Res., 117, D05306, doi:10.1029/ 2011JD016828.

Moffat, A. S., 1998: Global nitrogen overload problem grows critical. Science, 279, 988-989, doi:10.1126/science.279.5353.988.

Morgan, C., and N. Owens, 2001: Benefits of water quality policies: The Chesapeake Bay. Ecol. Econ., 39, 271-284, doi:10.1016/ S0921-8009(01)00212-9.

Mudway, I. S., and F. J. Kelly, 2000: Ozone and the lung: A sensitive issue. Mol. Aspects Med., 21, 1-48, doi:10.1016/ S0098-2997(00)00003-0.

Mueller, S. F., E. M. Bailey, T. M. Cook, and Q. Mao, 2006: Treatment of clouds and the associated response of atmospheric sulfur in the Community Multiscale Air Quality (CMAQ) modeling system. Atmos. Environ., 40, 6804-6820, doi:10.1016/j.atmosenv.2006.05.069.

National Research Council, 1995: Understanding Marine Biodiversity. National Academies Press, 128 pp.

Ortega, S., M. R. Soler, M. Alarcón, and R. Arasa, 2009: MNEQA, an emissions model for photochemical simulations. Atmos. Environ., 43, 3670-3681, doi:10.1016/j.atmosenv.2009.04.046.

Parra, R., P. Jiménez, and J. M. Baldasano, 2006: Development of the high spatial resolution EMICAT2000 emission model for air pollutants from the north-eastern Iberian Peninsula (Catalonia, Spain). Environ. Pollut., 140, 200-219, doi:10.1016/ j.envpol.2005.07.021.

Pérez, C., P. Jiménez, O. Jorba, M. Sicard, and J. M. Baldasano, 2006: Influence of the PBL scheme on high-resolution photochemical simulations in an urban coastal area over the western Mediterranean. Atmos. Environ., 40, 5274-5297, doi:10.1016/j.atmosenv.2006.04.039.

Pleim, J. E., 2006: A simple, efficient solution of flux-profile relationships in the atmospheric surface layer. J. Appl. Meteor. Climatol., 45, 341-347, doi:10.1175/JAM2339.1.

— 2007: A combined local and nonlocal closure model for the atmospheric boundary layer. Part I: Model description and testing. J. Appl. Meteor. Climatol., 46, 1383-1395, doi:10.1175/ JAM2539.1.

_ , and J. S. Chang, 1992: A non-local closure model for vertical mixing in the convective boundary layer. Atmos. Environ., 26, 965-981, doi:10.1016/0960-1686(92)90028-J.

— A. Xiu, P. L. Finkelstein, and T. L. Otte, 2001: A coupled land-surface and dry deposition model and comparison to field measurements of surface heat, moisture, and ozone fluxes. Water Air Soil Pollut. Focus, 1, 243-252, doi:10.1023/ A:1013123725860.

Ramanathan, V., and Y. Feng, 2009: Air pollution, greenhouse gases and climate change: Global and regional perspectives. Atmos. Environ., 43, 37-50, doi:10.1016/j.atmosenv.2008.09.063.

Sachse, G. W., G. F. Hill, L. O. Wade, and M. G. Perry, 1987: Fastresponse, high-precision carbon monoxide sensor using a tunable diode laser absorption technique. J. Geophys. Res., 92, 2071-2081, doi:10.1029/JD092iD02p02071.

— , R. C. Harriss, J. Fishman, G. F. Hill, and D. R. Cahoon, 1988: Carbon monoxide over the Amazon basin during the 1985 dry season. J. Geophys. Res., 93, 1422-1430, doi:10.1029/ JD093iD02p01422.

Samet, J. M., F. Dominici, F. C. Curriero, I. Coursac, and S. L. Zeger, 2000: Fine particulate air pollution and mortality in 20 U.S. cities, 1987-1994. N. Engl. J. Med., 343, 1742-1749, doi:10.1056/NEJM200012143432401.

Sanders, G. E., J. J. Colls, and A. G. Clark, 1992: Physiological changes in Phaseolus vulgaris in response to long-term ozone exposure. Ann. Bot., 69, 123-133.

San José, R., J. L. Pérez, and R. M. González, 2007: An operational real-time air quality modelling system for industrial plants. Environ. Modell. Software, 22, 297-307, doi:10.1016/ j.envsoft.2005.07.030.

Shine, K. P., 2000: Radiative forcing of climate change. Space Sci. Rev., 94, 363-373, doi:10.1023/A:1026752230256.

Skamarock, W. C., and Coauthors, 2008: A description of the Advanced Research WRF version 3. NCAR Tech. Note NCAR/TN-475+STR, 113 pp. [Available online at http:// www.mmm.ucar.edu/wrf/users/docs/arw_v3_bw.pdf.]

Stauffer, R. M., and Coauthors, 2014: Bay breeze influence on surface ozone at Edgewood, MD during July 2011. J. Atmos. Chem., doi:10.1007/s10874-012-9241-6, in press.

Steele, C. J., S. R. Dorling, R. von Glasow, and J. Bacon, 2013: Idealized WRF model sensitivity simulations of sea breeze types and their effects on offshore windfields. Atmos. Chem. Phys., 13, 443-461, doi:10.5194/acp-13-443-2013.

Stein, A. F., V. Isakov, J. Godowitch, and R. R. Draxler, 2007: A hybrid modeling approach to resolve pollutant concentrations in an urban area. Atmos. Environ., 41, 9410-9426, doi:10.1016/ j.atmosenv.2007.09.004.

Tzortziou, M., J. R. Herman, A. Cede, C. P. Loughner, N. Abuhassan, and S. Naik, 2014: Spatial and temporal variability of ozone and nitrogen dioxide over a major urban estuarine ecosystem. J. Atmos. Chem., doi:10.1007/ s10874-013-9255-8, in press.

Vukovich, J. M., and T. Pierce, 2002: The implementation of BEIS3 within the SMOKE modeling framework. Proc. 11th Int. Emission Inventory Conf., Atlanta, GA, EPA, 7 pp. [Available online at http://www.epa.gov/ttn/chief/conference/ei11/ modeling/vukovich.pdf.]

Wang, J., and Coauthors, 2013: Mesoscale modeling of smoke transport over the Southeast Asian Maritime Continent: Interplay of sea breeze trade wind, typhoon, and topography. Atmos. Res., 122, 486-503, doi:10.1016/j.atmosres.2012.05.009. 
Wiedinmyer, C., S. K. Akagi, R. J. Yokelson, L. K. Emmons, J. A Al-Saadi, J. J. Orlando, and A. J. Soja, 2011: The Fire INventory from NCAR (FINN): A high resolution global model to estimate the emissions from open burning. Geosci. Model Dev., 4, 625-641, doi:10.5194/gmd-4-625-2011.

Xiu, A., and J. E. Pleim, 2001: Development of a land surface model. Part I: Application in a mesoscale meteorological model. J. Appl. Meteor., 40, 192-209, doi:10.1175/ 1520-0450(2001)040<0192:DOALSM>2.0.CO;2.

Yarwood, G., S. Rao, M. Yocke, and G. Z. Whitten, 2005: Updates to the Carbon Bond Mechanism: CB05. Yocke and Company Final Rep. to the U.S. EPA RT-0400675, 161 pp. [Available online at http://www.camx.com/publ/pdfs/cb05_final_report_ 120805.pdf.]

Yu, S., and Coauthors, 2012: Comparative evaluation of the impact of WRF/NMM and WRF/ARW meteorology on CMAQ simulations for $\mathrm{PM}_{2.5}$ and its related precursors during the 2006 TexAQS/GoMACCS study. Atmos. Chem. Phys., 12, 4091-4106, doi:10.5194/acp-12-4091-2012.

Yu, Y., R. S. Sokhi, N. Kitwiroon, D. R. Middleton, and B. Fisher, 2008: Performance characteristics of MM5-SMOKE-CMAQ for a summer photochemical episode in southeast England, United Kingdom. Atmos. Environ., 42, 4870-4883, doi:10.1016/ j.atmosenv.2008.02.051. 